Analysis of Ship Accidents in Turkish Territories: A Data Mining Application

\title{
Türk Karasularında Meydana Gelen Gemi Kazalarının Analizi: Bir Veri Madenciliği Uygulamasi
}

\author{
Ahmet KARABACAK ${ }^{1, *}$ (D), Burak KÖSEOĞLU ${ }^{2}$ \\ ${ }^{1}$ Directorate General of Coastal Safety, İzmir, Turkey \\ ${ }^{2}$ Dokuz Eylül University, Maritime Faculty, Maritime Transportation and Management Engineering, Tinaztepe \\ Campus, 35160 Kuruçeşme-Buca, İzmir, Turkey
}

\begin{abstract}
Maritime transportation which mediates the transmission of major part of the world's trading volume is a type of transportation with high probability of encountering dangerous situations due to the instability of its conditions. In the past years, it became clear that the even smallest negativity caused perilous results. Thus, accurate implementation and evaluation of sea accident analysis is important to establish a policy for developing preventive measures and increasing awareness by determining the reason of accident. Analysis of sea accidents forms the fundamental subject of the study with data mining method which allow us to make estimated and definitive interpretations with computer programs by accessing significant information within large data stacks. In this study sea accidents occurring in Turkish territorial waters have been reviewed. In this context, the purpose of the study consists of determining which factors conduct together in sea accidents by association rule which is one of analysis methods of data mining. As a result of analysis, it has been determined that ship's loading condition, existence of maritime pilot in the ship, conditions of equipments such as bow thruster and quarterdeck thruster, ship flag and type and meteorological elements have been effective factors on the subject.
\end{abstract}

Keywords: Data Mining, Turkish Territorial Waters, Marine Accidents, Marine Safety, Association Rule

To cite this article: Karabacak, A., Köseoğlu, B., (2021). Analysis of Ship Accidents in Turkish Territories: A Data Mining Application, Turkish Journal of Maritime and Marine Science 7 (1): 54-74, DOI: https://doi.org/10.52998/trjmms.789498. 


\section{ÖZET}

Dünya ticaret hacminin büyük bir bölümünün taşınmasına aracılık eden denizyolu taşımacılığı, içinde bulunduğu koşulların değişkenliğinden ötürü her an tehlike ile karşılaşılma olasılığı yüksek bir taşımacılık türüdür. Yaşanabilecek en ufak bir olumsuzluğun dahi çok tehlikeli sonuçlar doğurduğu geçmiş yıllarda görülmüştür. Bu sebeple kaza nedenlerini tespit ederek farkındalığı artırmak, önleyici tedbirler geliştirmek için politika oluşturmak adına deniz kaza analizlerinin doğru bir biçimde yapılması ve değerlendirilmesi büyük önem arz etmektedir. Büyük veri yığınları içinden anlamlı bilgilere ulaşıp bilgisayar programlarıyla tahmin edici ve tanımlayıcı yorumlar yapmamıza olanak sağlayan veri madenciliği yöntemiyle deniz kazalarının analizinin yapılması çalışmanın temel konusunu oluşturmaktadır. $\mathrm{Bu}$ çalışmada Türk karasularında gerçekleşen deniz kazaları incelenmiştir. Bu bağlamda çalışmanın amacını deniz kazalarında hangi değişkenlerin birlikte hareket ettiğini, veri madenciliğinin önemli analiz yöntemlerinden biri olan birliktelik kuralıyla tespit etmek oluşturmaktadır. Yapılan analizler neticesinde kazalarda;gemi yük durumu, gemide kılavuz kaptanın varlığı, baş iter ve kıç iter gibi donanımların durumu, gemi bayrağı, gemi tipi ve meteorolojik etkenlerin etkili birer değişken olduğu tespit edilmiştir.

Anahtar Kelimeler: Veri Madenciliği, Türk Karasuları,Deniz Kazaları, Deniz Emniyeti, Birliktelik Kuralı

\section{GíRiş}

Ticaretin gelişmesindeki payı göz ardı edilemeyecek olan deniz taşımacılığı, tek seferde çok miktarda yükü en az maliyetle iki nokta arasında taşıdığ 1 için ulaştırma ve ticaret sektörünün merkezinde yer almakta ve paralel şekilde büyümektedir. Son yıllarda on milyar ton'un üzerine çıkan deniz taşımacılığı hacmindeki bu büyüme, ilk başta daha basit ve küçük tasarlanan gemilerin her geçen gün gelişmesine ve çoğalarak deniz ulaştırma sektörüne dâhil olmasına neden olmuştur (UNCTAD, 2017). Böylesine büyük bir ekonomik değerin taşınmasında rol üstlenen ticaret gemileri ve diğer deniz araçları, deniz, can, mal ve çevre emniyetini sağlamak, oluşabilecek olumsuzlukları engellemek adına çeşitli düzenlemelerle kontrol altında tutulmaya çalışılmaktadır. Küresel ticaretin artışıyla paralellik gösteren deniz taşımacılığı, yaşanan krizlere rağmen artarak devam etmektedir. Taşımacılık sektörü 1999 yılında 5,23 milyar ton (UNCTAD 2000:3) iken 2019 sonu itibariyle 11,076 milyar ton seviyelerine ulaşmış ve iki katından fazla bir artış göstermiştir (UNCTAD 2020: 4). Dünya genelinde 1000 Gross Ton (GRT) ve üzeri gemiler 1 Ocak 2020'de 52961 adetle 2061944000 DWT hacme ulaşmış ve bir önceki y1la göre hacimsel olarak \%4.1'lik bir büyüme göstermiş, ülkemiz ise 1528 parça gemi ve 28090402 DWT'la sektördeki yerini almıştır (UNCTAD, 2020: 37,41). Deniz ulaşımının artmasıyla denizde yaşanan kaza ve olay sayıları da artmaktadır (Acharya ve ark., 2017: 114).

Kaza analizleri incelendiğinde insan faktörünün deniz kazası sıralamasında önde olduğu görülmektedir. Bununla birlikte kazaların tek bir sebeple değil birbiriyle ilişkili birden çok nedenin birleşmesiyle oluştuğu tespit edilmiştir (Asyal1, 2014: 11). Bir başka çalışmda, deniz kazalarının yaklaşık \%50'sinin insan hatası ile doğrudan, \%30'unun ise kazadan kaçınmak için yapılan, insanla ilişkili hatalardan kaynaklandı̆̆ tespit edilmiştir (Baker ve Seah, 2004: 225). Avrupa Deniz Emniyeti Ajansı (EMSA) 2020 raporunda 2014-2019 y1ları arasinda gerçekleşmiş ve analizi tamamlanan 1801 kazanın \%54'ünün sebebini doğrudan insan faktörü olarak, \%28'ini de sistem/ ekipman hatası olarak belirlemiştir (EMSA, 2020: 25). Tanker gemilerinde yaşanmış kazalardan; çatışma ile sonuçlanan kazalarının \%63'ü, karaya oturma ile neticelenen kazalarının ise $\% 68$ 'i, insan hatası kaynaklı temel faktörlerin bir araya gelmesiyle gerçekleştiği görülmüştür (Uğurlu, 2013: 173). Hanzu-Pazara ve ark. (2008)'na göre başta çatışma olmak üzere kazaların yaklaşık \%75-96'sina, kismen de olsa insan hatasi neden olmuştur (Hanzau-Pazara ve ark., 2008: 4). Son 
30 yılda Uluslararası Denizcilik Örgütü-Küresel Entegre Taşımacılık Bilgi Sistemi (IMOGISIS)'ne raporlu deniz kazaları incelendiğinde, yaşanan kazaların \%73.352'si, kıyı bölgesi (karadan 12 deniz mili), adalar, nehir, kanal, iç sular, liman yaklaşımı, iç liman, demir bölgesi, rıhtım/ iskelelerde oluşmuş, çatışma ise yaşanan kaza tipleri arasında ilk sırayı almıştır (IMO, 2018). $\mathrm{Bu}$ da bize kazaların daha çok manevraların ve deniz trafiğinin yoğun yaşandığı bölgelerde, dar kanal ve boğazlarda meydana geldiğini göstermektedir. Bununla birlikte 19162017 yaşanan kazaların \%76.94'lük büyük bölümünü kilavuzlanmamış gemiler oluşturmuştur (IMO, 2018). Gemilerin açık denizlerde, bazı liman yaklaşımlarında ve demir bölgelerinde genellikle k1lavuzsuz manevra yaptığı göz önüne alındığında bu oran doğal karşılanabilir. Nitekim İstanbul ve Çanakkale boğazlarında 2001-2016 yılları arasında meydana gelen kazaların türleri ve gemilerin kılavuzlu olup olmaması arasındaki ilişki incelendiğinde İstanbul boğazında gemilerin karıştığı kaza türleri ve kılavuz kaptan arasında zayıf bir ilişki bulunurken Çanakkale boğazında ise ilişki yoktur sonucuna ulaş1lmıştır (Ece ve Özdemir, 2017: 75). Dünyanın farklı ülkelerinde yaşanan kazalar ve türleri incelendiğinde birinci sırayı çatışmanın aldığı görülmektedir. EMSA'nın 2014-2020 tarihli yayınladığı raporda $\mathrm{AB}$ üye ülke sularında meydana gelen kazaların ana gemi kategorilerinde dağılımında yük gemileri \%44'le, tipleri açısından ise çatışma \%22.6'l1k oranla ilk sıradaki yerini almıştır. (EMSA, 2020:12, 51). 2015-2019 yılları arasında çatışma; Kanada \%27.98 (TSCB: 2015, 2016 2017, 2018, 2019), Japonya \%28.22 (JTSB: 2015, 2016, 2017, 2018, 2019), Hong Kong \%39.53 (Mardep: 2015, 2016, 2017, 2018, 2019) ve Almanya \%55.64 (BSU: 2015, 2016, 2017, 2018,2019 ) oranlarla kaza tipleri bakımından ilk sirada bulunmaktadır.

Ülkemizde Türkiye İstatistik Kurumu (TUIK), T.C. Ulaştırma ve Altyapı Bakanlığı (UAB), Deniz Ticareti Genel Müdürlüğü (DTGM) kaza istatistiklerini ve raporlarını yayınlamaktadır. Deniz kazalarının düzenli ve doğru analizi, oluşmuş kazalardan ders çıkararak bu kazaların tekrarlanmaması için çeşitli önlemler geliştirmek adına çok önemlidir. Kaza analizleri ile ilgili dünya genelinde yapılan, literatüre kazandırılmış çalışmaların bazıları Tablo 1'de sunulmuştur.

Dünyada ve ülkemizde alınan tüm tedbirlere rağmen, deniz kazalarının önüne geçilememektedir. Yaşanabilecek en ufak bir olumsuzluğun dahi çok büyük neticeler doğurduğu geçmiş yıllarda görülmüştür. $\mathrm{Bu}$ sebeple kaza nedenlerini tespit ederek farkındalığı artırmak, önleyici tedbirler geliştirmek için politika oluşturmak adına, deniz kaza analizlerinin doğru bir biçimde yapılması ve değerlendirilmesi büyük önem arz etmektedir. Geçmiş yıllarda yapılmış çalışmalar neticesinde genellikle insan merkezli olan deniz kazalarının meydana gelmesinde etken olan başkaca faktörleri tespit etmek, hangi etmenlerin kaza oluşumunda önemli rol oynadığının tespiti, kök nedenlerin oluşumuna hangi değişkenlerin etki ettiği, değişkenler arasında nasıl bir ilişkinin olduğu ve bu değişkenlerin hangilerinin birlikte gerçekleştiği sorularının tespiti adına Türk karasularında meydana gelen kazaların analizi, veri madenciliği yöntemlerinden biri olan birliktelik kuralı ile incelenecektir. Böylece hem kaza birlikteliklerini tespit etmek hem de farklı bir yöntemle deniz kazalarının analizini gerçekleştirip literatüre katkı sunmak hedeflenmiştir. 
Karabacak and Köseoğlu, Turkish Journal of Maritime and Marine Sciences, 7(1): 54-74

Tablo 1. Deniz Kazaları İle İlgili Yapılmış Bazı Çalışmalar

\begin{tabular}{|c|c|c|c|c|c|c|}
\hline \multicolumn{7}{|c|}{ Deniz Kazaları İle İlgili Yapılan Çalışmalar Taraması } \\
\hline No & $\begin{array}{c}\text { Yayın } \\
\text { Yilı } \\
\end{array}$ & Yazarın Adı & Yayın Yeri & Makale adı & $\begin{array}{l}\text { Araştırmanın } \\
\text { Yöntemi } \\
\end{array}$ & Araştırmanın Bulguları \\
\hline 1 & 1988 & \begin{tabular}{|c|} 
Louis A. Le \\
Blanc, Paul \\
Gary Wyckoff
\end{tabular} & $\begin{array}{c}\text { Transportation } \\
\text { jurnal }\end{array}$ & $\begin{array}{l}\text { New Orleans Gemi Trafik } \\
\text { Hizmetinin Stratejik Başarı } \\
\text { Faktörü Analizi }\end{array}$ & Regresyon analizi & $\begin{array}{l}\text { VTS in hem kazaları önlemede ve hemde kazalar sonucu ortaya çıkacak büyük } \\
\text { maliyetleri engellemek adına faaliyetlerinin önemi ortaya konmuştur. }\end{array}$ \\
\hline 2 & 1997 & $\begin{array}{l}\text { K. W. Ketkar } \\
\text { ve A. J. G. } \\
\text { Babu }\end{array}$ & $\begin{array}{c}\text { Transpn Res.- } \\
D\end{array}$ & $\begin{array}{c}\begin{array}{c}\text { Gemi Trafik kazalarından } \\
\text { oluşan petrol sızıntılarının bir } \\
\text { analizi }\end{array} \\
\end{array}$ & $\begin{array}{c}\text { Regresyon analizi } \\
\text { yöntemi }\end{array}$ & $\begin{array}{l}\text { Petrol sızıntısı boyutunun logaritması ile olayın boyutunun logaritması arasında } \\
\text { kuvvetli bir doğrusal ilişki teyit edilmiştir.Gemilerin boyutlarının artmasıyla, } \\
\text { ABD sularında daha büyük petrol sızıntısı riski bulunduğu ortaya konmuştur. }\end{array}$ \\
\hline 3 & 2005 & $\begin{array}{c}\text { Talley W. K. } \\
\text { ve arkadaşları }\end{array}$ & \begin{tabular}{c|} 
Maritime \\
Policy \& \\
Management \\
\end{tabular} & $\begin{array}{c}\text { Gemi kazalarında mürettebat } \\
\text { yaralanmalarının ciddiyetinin } \\
\text { belirlenmesi }\end{array}$ & \begin{tabular}{|c|}
$\begin{array}{c}\text { Poisson ve negatif } \\
\text { binomiyal } \\
\text { regresyon }\end{array}$ \\
\end{tabular} & $\begin{array}{c}\text { Ölümcül olmayan yaralanmalar yük gemilerinde gemi yaşının artmasıyla, tanker } \\
\text { ve römorkörlerde ise ölümcül yaralanmalar sırasıyla yangın ve alabora } \\
\text { durumlarında artış göstermiştir }\end{array}$ \\
\hline 4 & 2009 & $\begin{array}{l}\text { Özgecan S. } \\
\text { Ulusçu ve } \\
\text { arkadaşları }\end{array}$ & Risk Analises & $\begin{array}{l}\text { İstanbul Boğazında Gemi } \\
\text { Trafiğinin Risk Analizi }\end{array}$ & $\begin{array}{l}\text { Simülasyon ve } \\
\text { matematiksel } \\
\text { modelleme }\end{array}$ & $\begin{array}{l}\text { Yerel trafik yoğunluğu ve pilotaj, İstanbul Boğazı'ndaki riskleri etkileyen iki ana } \\
\text { faktör olarak ortaya çıkmıştır. İstanbul Boğazı'ndaki mevcut operasyonların, } \\
\text { risklerin, hem de gemi gecikmelerinin kabul edilemez olduğu kritik bir seviyeye } \\
\text { geldiğini ifade eder. }\end{array}$ \\
\hline 5 & 2009 & Carl Macrae & $\begin{array}{c}\text { Maritime } \\
\text { Policy \& } \\
\text { Management }\end{array}$ & $\begin{array}{c}\text { Denizdeki insan faktörleri: } \\
\text { karaya oturma ve çatışmalarda } \\
\text { ortak hatalar }\end{array}$ & $\begin{array}{c}\text { CREAM ve Deniz } \\
\text { Kazası Araştırma } \\
\text { Aracı (MAIT) }\end{array}$ & $\begin{array}{c}\text { Karaya oturmalar genellikle, seyir sırasında geminin pozisyon tespitinde bir } \\
\text { sorun ya da köprüüstündeki iletişim sorunları ile seyrin yeterince } \\
\text { planlanamamasıla birleşince olur. }\end{array}$ \\
\hline 6 & 2010 & $\begin{array}{l}\text { Tracey Dalton } \\
\text { ve Di Jin }\end{array}$ & $\begin{array}{l}\text { Marine } \\
\text { Pollution } \\
\text { Bulletin }\end{array}$ & $\begin{array}{c}\text { ABD deniz koruma alanlarında } \\
\text { gemi petrol sızıntılarının } \\
\text { yaygınlığ } 1 \text { ve sıklığ } 1\end{array}$ & $\begin{array}{l}\text { Adimsal } \\
\text { Regresyon }\end{array}$ & $\begin{array}{l}\text { Hassas kaynakların petrol sızıntılarına karşı savunmasızlığını azaltan Deniz } \\
\text { Koruma Alanı kuralları ve deniz nakliye politikaları geliştirmek için } \\
\text { kullanılabilir. }\end{array}$ \\
\hline 7 & 2011 & $\begin{array}{l}\text { Martin Hassel } \\
\text { ve arkadaşları }\end{array}$ & $\begin{array}{c}\text { Accident } \\
\text { Analysis and } \\
\text { Prevention } \\
\end{array}$ & $\begin{array}{c}\text { Deniz kazalarının gemi kaza } \\
\text { veritabanlarına yetersiz rapor } \\
\text { edilmesi }\end{array}$ & $\begin{array}{l}\text { Karşılaştırmalı } \\
\text { analiz. }\end{array}$ & $\begin{array}{c}\text { Kaza raporlamada ilk sırada Norveç, son sırada ise ABD bulunmaktadır. } \\
\text { Ortalama olarak, çalışma sonuçları, rapor edilmemiş kazaların sayısının meydana } \\
\text { gelen kazaların yaklaşık\% 50'sini oluşturduğunu belgelemektedir. }\end{array}$ \\
\hline 8 & 2013 & $\begin{array}{l}\text { Christine } \\
\text { Chauvin ve } \\
\text { arkadaşları }\end{array}$ & $\begin{array}{l}\text { Accident } \\
\text { Analysis and } \\
\text { Prevention }\end{array}$ & $\begin{array}{l}\text { Deniz kazalarında insan ve } \\
\text { organizasyonel faktörler: } \\
\text { HFACS ile denizde } \\
\text { çatışmaların analizi }\end{array}$ & Çoklu kaza analizi & $\begin{array}{c}\text { Çoğu çatışmanın hatalı kararlardan kaynaklandığını gösteriyor. Ön koşul } \\
\text { düzeyinde, kötü görüş koşulları ve araçların yanlış kullanımı (çevre faktörleri), } \\
\text { durumsal farkındalık veya dikkat eksikliği (operatörlerin koşulları) kaybı, gemi } \\
\text { içi iletişimlerde veya Köprü Üstü Kaynak Yönetimindeki (personel faktörleri) } \\
\text { eksiklikler çatışmanın yaşanmasında ciddi etkenler olarak sıralanmıştır. }\end{array}$ \\
\hline 9 & 2014 & $\begin{array}{c}\text { Yusuf Volkan } \\
\text { Aydogdu }\end{array}$ & $\begin{array}{c}\text { The Journal Of } \\
\text { Navigation }\end{array}$ & $\begin{array}{c}\text { İstanbul Boğazındaki Deniz } \\
\text { Riski Algılama ve Kaza } \\
\text { İstatistiklerinin } \\
\text { Karşılaştırılması }\end{array}$ & \begin{tabular}{|c|} 
Genel Fuzzy \\
Analitik Hiyerarşi \\
Süreci (Yüzyüze \\
görüşme)
\end{tabular} & $\begin{array}{c}\text { Katılımcıların risk algılamaları ile istatistiksel deniz kazaları verileri } \\
\text { karşılaşırıldığında, risk algılaması ile istatistiksel veriler arasında temel bir } \\
\text { tutarsızlık olduğu ortaya çıkmaktadır. Özellikle en yüksek kaza sayısına sahip } \\
\text { olan Boğaz, nispeten düşük riskli olarak algılanırken, yüksek riskli olarak } \\
\text { algılanan alanlarda daha az kaza yaşanmıștır. }\end{array}$ \\
\hline
\end{tabular}


Tablo 1. Deniz Kazaları İle İlgili Yapılmış Bazı Çalışmalar (Devamı)

\begin{tabular}{|c|c|c|c|c|c|c|}
\hline 10 & 2015 & Nur Jale Ece & \begin{tabular}{|c|} 
Journal of ETA \\
Maritime \\
Science
\end{tabular} & $\begin{array}{c}\text { Kılavuzluk Hizmetlerinin } \\
\text { Deniz Emniyetine Katkısı: } \\
\text { İstanbul Boğazı'nda Kazaya } \\
\text { Karışan Gemiler İle Kılavuz } \\
\text { Kaptan Almaları Arasındaki } \\
\text { İlişkinin Analizi } \\
\end{array}$ & \begin{tabular}{|c|} 
İstatistiksel analiz \\
yöntemi (SPSS \\
$17.00)$
\end{tabular} & $\begin{array}{c}\text { Kılavuz kaptan almanın kazaları azalttığı, kılavuz hizmetlerinde rekabetin } \\
\text { kazalara neden olduğu ve söz konusu analizlerden elde edilen bulgularda İstanbul } \\
\text { Boğazı'nda söz konusu dönemde en çok kazaya kılavuz kaptan almayan } \\
\text { gemilerin karıştığı sonucuna varılmıştır. }\end{array}$ \\
\hline 11 & 2015 & $\begin{array}{l}\text { Umut Yıldırım } \\
\text { ve arkadaşları }\end{array}$ & \begin{tabular}{|c|} 
Journal of ETA \\
Maritime \\
Science
\end{tabular} & $\begin{array}{l}\text { Karaya Oturma Kazalarında } \\
\text { İnsan Hatası: Konteyner } \\
\text { Gemileri için Örnek Çalışma }\end{array}$ & AHP & $\begin{array}{l}\text { Konteyner gemilerinde karaya oturma kazalarının önlenmesinde en önemli } \\
\text { etmenlerin sırasıyla güverte vardiya zabiti sayısının artırımı, gemi öncesi ve } \\
\text { gemide eğitim, köprüüstü kaynak yönetimi, gemi içi uygulamaları, gözcü } \\
\text { kullanılması ve son olarak ECDIS cihazı olduğu belirlenmiştir. }\end{array}$ \\
\hline 12 & 2016 & Emre Akyüz & Safety Science & $\begin{array}{c}\text { Kargo gemilerindeki } \\
\text { potansiyel operasyonel } \\
\text { nedenleri değerlendirmek için } \\
\text { bir deniz kazası analiz modeli }\end{array}$ & $\begin{array}{l}\text { Hibrit kaza analiz } \\
\text { modeli (ANP VE } \\
\text { HFACS) }\end{array}$ & $\begin{array}{c}\text { Kaza önleyici faktörler: Gemi emniyet yönetim sistemini tekrar dizayn ederek ve } \\
\text { gemi içi tetkikleri sıklaştırarak gemide SMS in uygulandığına emin olmak, kötü } \\
\text { çalışma ortamını en aza indirgemek için şirket temelli desteği etkinleştirme, } \\
\text { eksiklikleri gidermek için iç ve dış denetimler kalifiye personelle yapılmalı. }\end{array}$ \\
\hline 13 & 2017 & $\begin{array}{c}\text { Bekir Şahin ve } \\
\text { Yupo Chan }\end{array}$ & $\begin{array}{l}\text { Pamukkale } \\
\text { Univ Muh } \\
\text { Bilim Derg }\end{array}$ & $\begin{array}{l}\text { Risk assessment of the Istanbul } \\
\text { Strait by using Ports and } \\
\text { Waterways Safety Assessment } \\
\text { (PAWSA) method }\end{array}$ & Delphi & $\begin{array}{c}\text { Çevre için risk kriteri seviyesinin } 9 \text { üzerinden } 8,4 \text { ve Türk boğazlarında } \\
\text { kılavuzsuz seyir riskinin } 8,7 \text { olduğu, VTS'intrafiği düzenleyerek bu riski kısmen } \\
\text { azaltarak 7'ye düşürdüğü fakat kılavuzluk hizmetini kullanan gemiler için riskin } \\
9 \text { üzerinden } 5.7 \text { ye düştüğü tespit edilmiştir. }\end{array}$ \\
\hline 14 & 2019 & \begin{tabular}{|} 
Türkistanlı \\
Talip ve \\
Kuleyin Barış
\end{tabular} & $\begin{array}{l}\text { Mersin } \\
\text { University } \\
\text { Journal of } \\
\text { Maritime } \\
\text { Faculty }\end{array}$ & $\begin{array}{l}\text { Denizde Çarpışmayı Önlemek } \\
\text { İçin Durumsal Farkındalık Ve } \\
\text { Karar Verme Eğitimi: } \\
\text { Kuramsal Bir Arka Plan }\end{array}$ & Literatür taramas1 & $\begin{array}{c}\text { Araştırmalar, seyir vardiyasını sürdürmekten sorumlu olan gemideki denizcilerin } \\
\text { çatışmalara hem neden hem de engel olabileceğini öne sürüyor. Alandaki } \\
\text { çalışmaların önerileri, durumsal farkındalığı ve karar vermeyi geliştirmek için } \\
\text { özel eğitim ihtiyacına işaret etmektedir. }\end{array}$ \\
\hline
\end{tabular}




\section{MATERYAL VE YÖNTEM}

Araştırmada, üç tarafı denizlerle çevrili olan ülkemiz genelinde, Türk karasularında yaşanmış ve Ana Arama Kurtarma Koordinasyon Merkezi (AAKKM)'ne raporlanmış kazaların içerik analizleriyle, uzman görüşlerinden elde edilen bulgular çerçevesinde tespit edilen değişkenler doğrultusunda nicel analiz gerçekleștirilmiştir. Gemi kazaları ile ilgili yapılan nitel ve nicel araştırmalar sonucu kazalarla ilgili nedenlerle, kaza anındaki/ kaza sonucu oluşan değişkenler tespit edilerek veri madenciliği analizi için uygun veri seti oluşturulmuştur. $\mathrm{Bu}$ veriler içerik analiziyle değerlendirilip yorumlandıktan sonra, önceden oluşturulan veri seti, Weka programında bulunan farklı analiz yöntemleri ile incelenmiştir. En son etapta, en uygun analiz yöntemi olduğu düşünülen birliktelik kuralı denenmiş ve tüm süreç Şekil 1'de olduğu gibi gelişmiştir.

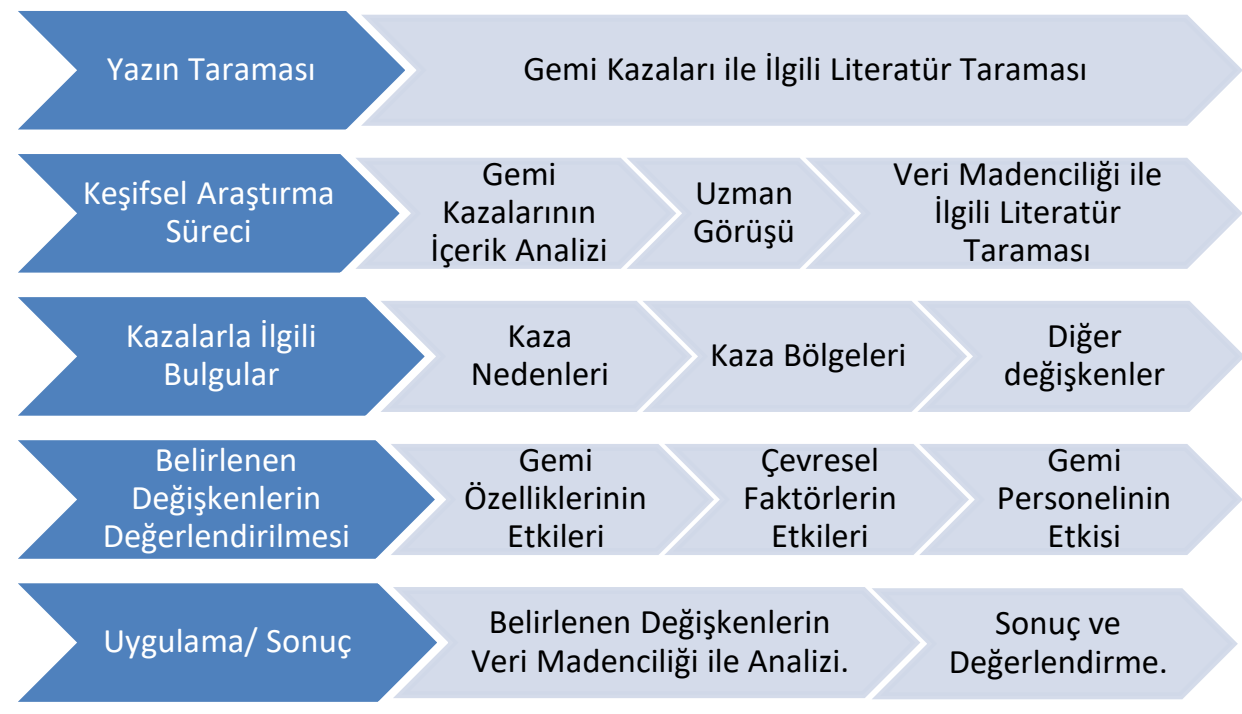

Şekil 1: Araştırma Süreci

Modelin oluşturulması sürecinde gemi kazalarıyla ilgili yapılan yazın taramasında gemi kazalarında oluşan değişkenler tespit edilmiş, kaza raporlarındaki değişkenlerle aralarındaki ilişki incelenmiştir. Uzman görüşlerinin de dâhil edilmesiyle kullanılacak değişkenler son halini almıştır. Kaza raporları tek tek incelenerek kaza/ olay'a karışan her bir geminin özgül ve teknik özellikleri (baş iter, boy, yapım yılı, bayrak vs.) ile birlikte kaza sonucu oluşlan çıktılar (kirlilik, maddi hasar, can kaybı vs.) başlıklar halinde sıralanmıştır. Buna ek olarak deniz ulaştırma sektöründe fiilen hizmet veren ve farklı tip gemilerde görevli; "gemi kaptanları", bu kaptanlara uluslararası mevzuat ve yönetmelik gereği rehberlik eden "kılavuz kaptanlar", karasularında ülkesi adına bölgesinde tek yetkili kurum olan "liman başkanlığında görevli bürokrat" ve denizcilik alanında yetişmiş insan tedarikinde görev alan "öğretim üyeleri" nden oluşan geniş yelpazeli uzman görüşlerinden faydalanarak analiz için kullanılacak değişkenlerin tespiti tamamlanmıştır. Görüşüne başvurulan uzmanlar, alanında deneyimli, uzakyol kaptan yeterliliğine sahip, 16-33 y1lları arasında tecrübe sahibi olan on kişiden oluşmuş ve Tablo 2'de sunulmuştur. 
Tablo 2. Uzman profil bilgileri

\begin{tabular}{|c|c|c|c|c|c|c|c|}
\hline No & Yeterlilik & $\begin{array}{l}\text { Toplam } \\
\text { Hizmet }\end{array}$ & Görevli Olduğu Kurum & $\begin{array}{c}\text { Genelde } \\
\text { Çalıştığı } \\
\text { Gemi }\end{array}$ & $\begin{array}{l}\text { Öğrenim } \\
\text { Durumu }\end{array}$ & Ünvanı & Yöntemi \\
\hline 1 & Uzk. Yol Kpt & 18 & $\begin{array}{l}\text { D.E.Ü Denizcilik } \\
\text { fakültesi }\end{array}$ & Tanker & L. Üstü & $\begin{array}{l}\text { Dr. Öğretim } \\
\text { Üyesi }\end{array}$ & Yüz yüze \\
\hline 2 & Uzk. Yol Kpt & 16 & $\begin{array}{l}\text { D.E.Ü Denizcilik } \\
\text { fakültesi }\end{array}$ & Kuru Yük & Fakülte & $\begin{array}{l}\text { Öğretim } \\
\text { Görevlisi }\end{array}$ & Yüz yüze \\
\hline 3 & Uzk. Yol Kpt & 33 & $\begin{array}{l}\text { Ulaştırma ve Altyapı } \\
\text { Bakanlığ KEGM }\end{array}$ & Kuru Yük & Fakülte & Baş Klv. Kpt & Yüz yüze \\
\hline 4 & Uzk. Yol Kpt & 28 & $\begin{array}{l}\text { Ulaştırma ve Altyapı } \\
\text { Bakanlığ1 KEGM }\end{array}$ & $\begin{array}{l}\text { Yolcu/ } \\
\text { Ro-ro }\end{array}$ & L.Üstü & Baş Klv. Kpt & Yüz yüze \\
\hline 5 & Uzk. Yol Kpt & 21 & $\begin{array}{l}\text { Ulaştırma ve Altyap1 } \\
\text { Bakanlığ1 KEGM }\end{array}$ & Kuru Yük & L. Üstü & Kilavuz Kpt & E-posta \\
\hline 6 & Uzk. Yol Kpt & 20 & $\begin{array}{l}\text { Med Marine Kılavuzluk } \\
\text { \& Römorkörcülük }\end{array}$ & Kuru Yük & Fakülte & Kilavuz Kpt & E-posta \\
\hline 7 & Uzk. Yol Kpt & 17 & Eastern Pasific Shipping & Tanker & $\begin{array}{l}\text { MYO\& } \\
\text { Fakülte }\end{array}$ & Gemi Kaptanı & E-posta \\
\hline 8 & Uzk. Yol Kpt & 20 & Oldendorff & Kuruyük & Fakülte & Gemi Kaptanı & E-posta \\
\hline 9 & Uzk. Yol Kpt & 30 & Arkas & Konteynır & Lise & Gemi Kaptanı & E-posta \\
\hline 10 & Uzk. Yol Kpt & 19 & $\begin{array}{c}\text { Ulaştırma ve Altyapı } \\
\text { Bakanlığ İzmir Lim. } \\
\text { Başk. }\end{array}$ & Kuruyük & Fakülte & $\begin{array}{l}\text { Gemi Denetim } \\
\text { Uzmanı }\end{array}$ & E-posta \\
\hline
\end{tabular}

Verilerin dijitalleşerek kaydedildiği günümüzde, herhangibir konu hakkında edinilmek istenen bilgi için onbinlerce sonuç çıkmakta, bilgi yığınları gittikçe artarak adeta içinden çıkılmaz sarmallar halini almaktadır. Veri madenciliği; bahse konu dijital veri yığınları içinden anlamlı veriler elde etmek için kullanılan etkin bir yöntemdir (Fayyad, 2001:62). Veri madenciliği modellerinin oluşumunda iki temel esas alınmaktadır. Bunların ilki verilerden elde edilen örüntülerle sonuçları bilinmeyen verilerin tahmininde kullanılan tahmin edici, diğeri ise mevcut verilerin tanımlanmasinda kullanılan tanımlayıcı modeldir (Han ve Kamber, 2001: 82). Tahmin edici modellemede sonuçlanmış verilerden faydalanılarak, sonuçları bilinmeyen, gelecekte oluşabilme olasılığı yüksek olayların sonuçlarını öngörmek hedeflenmektedir. Tanımlayıcı modellerde ise mevcut verilerdeki örüntülerle karar vermeye yardımcı olabilecek tanımlamalar yapilmaktadır. Veri madenciliğinde uygulanan ve temeli olarak kabul görmüş modeller Şekil 2'de görülmektedir (Dodunekov ve ark., 2012:17).

Veri Madenciliği, tahmin yürütebilmek adına gizli bilgileri çıkarmak için büyük miktarda ham veriyi analiz etme işlemidir. Yapay zekânın, veri tabanlarının, istatistiklerin ve makine öğrenmenin birleştiğgi bir disiplindir (Kouamou, 2011: 241-258). Denizcilik alanında veri madenciliği kullanımı ile ilgili yazın taraması sonucu elde edilen bulgulardan bazıları Tablo 3 'te sunulmuştur. 


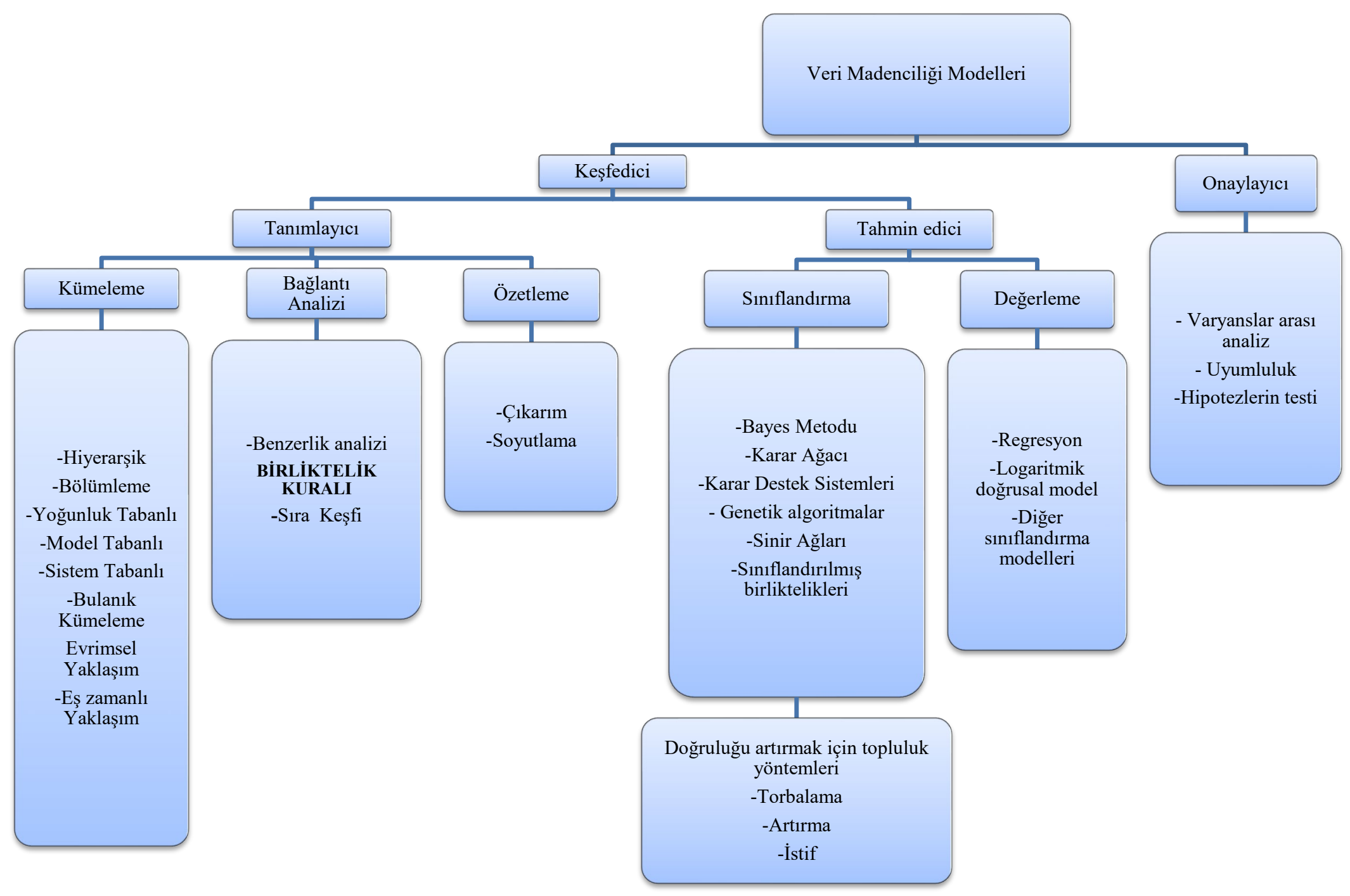

Şekil 2: Veri Madenciliği Modelleri (Dodunekov ve ark., 2012:17) 
Tablo 3. Veri Madenciliği Yöntemiyle Denizcilik ve Deniz Kazaları İle İlgili Yapılan Bazı Çalışmalar

\begin{tabular}{|c|c|c|c|c|c|c|}
\hline \multicolumn{7}{|c|}{ Denizcilikte ve Deniz Kazaları İle İlgili Yapılan Çalışmalar Taraması } \\
\hline No & Yil & Yazarın Adı & Yayın Yeri & Makale adı & $\begin{array}{l}\text { Araştırmanın } \\
\text { Yöntemi }\end{array}$ & Araştırmanın Bulguları \\
\hline 2 & 1995 & $\begin{array}{l}\text { N.A.J. Witt } \\
\text { ve diğerleri }\end{array}$ & $\begin{array}{l}\text { Marine Dynamics } \\
\text { Research Group }\end{array}$ & $\begin{array}{c}\text { Bir Gemi Rotasının Sinir A } \breve{g} 1 \\
\text { Kontrol Cihazıyla Yönlendirmesi }\end{array}$ & Sinir Ağları & $\begin{array}{l}\text { Nöral kontrol teorisi ile, rotanın sürdürülmesi amacı ile simülasyonda } \\
\text { matematiksel bir model uygulanarak yöntemi gerçek ortamda test etmek } \\
\text { için bir veri toplama ve entegre navigasyon sistemi içeren bir ölçek } \\
\text { modeli oluşturulmuştur. Yeni bir takip kontrol sistemi, uygulaması ve } \\
\text { denemelerle doğrulama yapılmıştır. }\end{array}$ \\
\hline 4 & 1996 & $\begin{array}{l}\text { L.A. Le } \\
\text { Blanck ve } \\
\text { C.T. Rucks } \\
\end{array}$ & $\begin{array}{l}\text { Accident Analysis } \\
\text { and Prevention }\end{array}$ & $\begin{array}{l}\text { Gemi Kazalarının Çoklu } \\
\text { Diskriminant Analizi }\end{array}$ & $\begin{array}{l}\text { Kümeleme ve } \\
\text { Diskriminant } \\
\text { Analizi }\end{array}$ & $\begin{array}{l}\text { Çalışmanın yapıldığ bölgede için kılavuz kaptan ve gemi trafik } \\
\text { hizmetlerinin kazalarda önleyici rol aldıkları tespit edilmiştir. }\end{array}$ \\
\hline 6 & 2000 & $\begin{array}{c}\text { Y.P. } \\
\text { Kondratenko } \\
\text { ve diğerleri }\end{array}$ & $\begin{array}{c}\text { IFAC Management } \\
\text { and Control of } \\
\text { Production and } \\
\text { Logistics }\end{array}$ & $\begin{array}{l}\text { Gemi Karar Verme Sistemleri } \\
\text { İçn Bulanık Mantık Yaklaşımı }\end{array}$ & $\begin{array}{l}\text { Bulanık Mantık } \\
\text { Algoritmaları ve } \\
\text { Karar Destek } \\
\text { Sistemleri } \\
\end{array}$ & $\begin{array}{l}\text { Gemi Stabilitesi ve Navigasyon Sistemlerinin Bulanık Mantık } \\
\text { Algoritmalarıyla birlikte eş zamanlı karar destek sistemlerin kullanarak } \\
\text { etkin bir yaklaşımla dar kanallarda emniyetli seyrin sağlanması }\end{array}$ \\
\hline 8 & 2001 & $\begin{array}{l}\text { W. Fricke ve } \\
\text { diğerleri }\end{array}$ & Marine Structures & $\begin{array}{c}\text { Çeşitli Sınıflandırma } \\
\text { Yaklaşımlarını Kullanarak Bir } \\
\text { Konteyner Gemisindeki Yapısal } \\
\text { Detayların Karşılaştırmalı } \\
\text { Yorulma Dayanımı } \\
\end{array}$ & Sinıflandırma & $\begin{array}{l}\text { Tahmini yorgunluk yaşamında } 1.8 \text { ila } 20.7 \text { yıl arasında değişen büyük } \\
\text { farklılıklar bulundu. Ayrıca, yapısal detayın yorulmadan kaynaklı } \\
\text { arızaların oluşumuna etki etmediği düşünülmesine rağmen, bu } \\
\text { hesaplama } 5.3 \text { yıllık nispeten kısa bir yorulma ömrü olduğunu } \\
\text { göstermiştir. }\end{array}$ \\
\hline 10 & 2005 & $\begin{array}{l}\text { V.L. } \\
\text { Dimitros ve } \\
\text { diğerleri }\end{array}$ & $\begin{array}{l}\text { WMU Journal of } \\
\text { Maritime Affais }\end{array}$ & \begin{tabular}{|c|} 
Güvenlik / Operasyonel ve Mali \\
Gereksinimlere Dayalı Yenilikçi \\
Bir Ekip Kompozisyonu \\
Yaklaşımına Giriş \\
\end{tabular} & Sinıflandırma & $\begin{array}{l}\text { Gemilere entegre edilecek teknolojik yenilikler ve var olan teknolojinin } \\
\text { yükseltilmesi personel donatımındaki sayının düşmesine ve finansal } \\
\text { faydalara yol açabileceği tespit edilmiştir. }\end{array}$ \\
\hline 13 & 2010 & $\begin{array}{l}\text { J. Montewka } \\
\text { ve diğerleri }\end{array}$ & $\begin{array}{l}\text { Reliability } \\
\text { Engineering and } \\
\text { System Safety }\end{array}$ & $\begin{array}{l}\text { Gemi Çatışmalarının Olasılık } \\
\text { Modellemeleri }\end{array}$ & $\begin{array}{l}\text { Monte Carlo ve } \\
\text { Genetik } \\
\text { Algoritmaları }\end{array}$ & $\begin{array}{l}\text { Oluşturulan modelde çatışmaların daha fazla engellenebildiği tespit } \\
\text { edilmiştir. Bununla birlikte oluşturulan model doğal ortamı birebir } \\
\text { yansıtmadığından daha fazla kaza önlemiş gibi görünebilir. }\end{array}$ \\
\hline 15 & 2011 & $\begin{array}{l}\text { A. Maki ve } \\
\text { diğerleri }\end{array}$ & $\begin{array}{l}\text { Journal of Marine } \\
\text { Science } \\
\text { Technology }\end{array}$ & $\begin{array}{c}\text { Gerçek kodlanmış bir genetik } \\
\text { algoritmaya dayanan gemi } \\
\text { dengesini sağlayan yeni bir hava- } \\
\text { rotalama sistemi }\end{array}$ & $\begin{array}{l}\text { Genetik } \\
\text { Algoritmalar }\end{array}$ & $\begin{array}{l}\text { Gerçek kodlanmış genetik algoritma tekniği (evrimsel bir hesaplama } \\
\text { tekniği), küresel olarak en uygun deniz yolun aranması için uygulanmış, } \\
\text { ekonomi ile gemi emniyeti arasındaki ilişkinin bir takas olduğu ve } \\
\text { güvenli yolun mutlaka en ekonomik olmadığ1 sayısal olarak } \\
\text { doğrulanmıştır. }\end{array}$ \\
\hline 16 & 2013 & $\begin{array}{l}\text { Chen ve } \\
\text { diğerleri }\end{array}$ & $\begin{array}{l}\text { Expert System } \\
\text { with Appications }\end{array}$ & $\begin{array}{c}\text { Denizcilik Durumsal } \\
\text { Farkındalığ İçin Genetik } \\
\text { Algoritma Kullanılarak Bilgi } \\
\text { Keşfi }\end{array}$ & $\begin{array}{l}\text { Genetik } \\
\text { Algoritmalar }\end{array}$ & $\begin{array}{c}\text { G.A metodolojisinin nadir görülen özlelliklere sahip gelen gemiler için } \\
\text { işlev gördüğünü ve denizdeki durumsal farkındalığı artırmak için yeterli } \\
\text { olduğunu göstermiştir. }\end{array}$ \\
\hline
\end{tabular}


Tablo 3. Veri Madenciliği Yöntemiyle Denizcilik ve Deniz Kazaları İle İlgili Yapılan Bazı Çalışmalar (Devamı)

\begin{tabular}{|c|c|c|c|c|c|c|}
\hline 17 & 2014 & H. Li & $\begin{array}{l}\text { Applied Mechanics } \\
\text { and Materials }\end{array}$ & $\begin{array}{l}\text { İnsan Faktörlerinin Sebep } \\
\text { Olduğu Çatışma Kazalarının } \\
\text { Oluşumunda Veri Madenciliğine } \\
\text { Dayalı Bir Mekanizma Çalışması }\end{array}$ & $\begin{array}{l}\text { Bayesian Belief } \\
\text { Network (BBN), } \\
\text { Apriori }\end{array}$ & $\begin{array}{l}\text { Bayesian ağ yapısı kullanılarak kazaya neden olan bir zincir } \\
\text { oluşturulmuş, } 120 \text { tipik durum Apriori algoritmasıla analiz edilmiştir. }\end{array}$ \\
\hline 22 & 2015 & $\begin{array}{l}\text { A.J. Davies } \\
\text { ve M.J. } \\
\text { Hope }\end{array}$ & $\begin{array}{l}\text { Marine Pollution } \\
\text { Bulletin }\end{array}$ & $\begin{array}{l}\text { Petrol sızıntısı müdahale } \\
\text { stratejisi seçimi için Bayesian } \\
\text { çıkarım temelli çevresel karar } \\
\text { destek sistemleri }\end{array}$ & $\begin{array}{l}\text { Bayes Ağ } 1 \text { ve } \\
\text { Karar Destek } \\
\quad \text { Sistemi }\end{array}$ & $\begin{array}{l}\text { Bayesian ağlarının kirletici madde salımını takiben beklenmedik durum } \\
\text { planlarının yeniden değerlendirilmesini ve yeniden onaylanmasını } \\
\text { kolaylaştırmak için uygun olduğu, böylece optimum müdahale } \\
\text { stratejisinin benimsenmesine yardımcı olduğu gösterilmiştir. Bu, orijinal } \\
\text { kirlilik olayının ötesinde ek çevresel ve sosyoekonomik hasara neden } \\
\text { olan alt-optimal müdahale stratejileri olasılığını minimize edebilir. }\end{array}$ \\
\hline 26 & 2018 & $\begin{array}{l}\text { H. Changhai } \\
\text { ve H. } \\
\text { Shenping }\end{array}$ & $\begin{array}{l}\text { Cluster } \\
\text { Computing }\end{array}$ & $\begin{array}{l}\text { Birliktelik Kuralı Öğrenme } \\
\text { Algoritmaları Kullanılarak Deniz } \\
\text { Kaza Veri Tabanında Faktör } \\
\text { Korelasyon madenciliği }\end{array}$ & $\begin{array}{l}\text { Birliktelik Kuralı } \\
\text { Apriori } \\
\text { Algoritması }\end{array}$ & $\begin{array}{l}\text { Deniz kaza sonuçlarından kaza sebepleri tespit edilmeye çalışmış ve şu } \\
\text { şekilde sıralanmıştır; beklenmeyen sebepler, doğal sebepler, suyolu- } \\
\text { rıhtım etkisi, trafik etkisi, gemi ve yük etkisi, diğer insan hatalarıve } \\
\text { personel hataları şeklinde sıralanmıștır. }\end{array}$ \\
\hline 27 & 2018 & $\begin{array}{l}\text { B. Yang ve } \\
\text { diğgerleri }\end{array}$ & $\begin{array}{l}\text { International } \\
\text { Conference on } \\
\text { Civil and } \\
\text { Hydraulic } \\
\text { Engineering }\end{array}$ & $\begin{array}{l}\text { Kümeleme ve Birliktekil Kuralı } \\
\text { İle Veri Madenciliğne Dayalı } \\
\text { Deniz Kazaları Analizi }\end{array}$ & $\begin{array}{l}\text { Kümeleme ve } \\
\text { Birliktelik Kuralı }\end{array}$ & $\begin{array}{c}3000 \text { grt altı kumcu gemileri ve balıkçı gemileri için kaza nedeni \%90 } \\
\text { üzerinde insan faktörü olarak tespit edilmiştir. }\end{array}$ \\
\hline 28 & 2019 & $\begin{array}{l}\text { K. Dikis ve } \\
\text { I. Lazakis }\end{array}$ & $\begin{array}{l}\text { International } \\
\text { Journal of Naval } \\
\text { Architecture and } \\
\text { Ocean Engineering }\end{array}$ & $\begin{array}{l}\text { Gemi Sistemlerinin Dinamik } \\
\text { Öngörüsel Güvenilirlik } \\
\text { Değerlendirmesi }\end{array}$ & $\begin{array}{l}\text { Bayesian Belief } \\
\text { Network (BBN), } \\
\text { K-Means }\end{array}$ & $\begin{array}{l}\text { Farklı, karmaşık gemis sistemlerinin öngörülü güvenilirlik } \\
\text { değerlendirmesi ve buna bağlı olarak Olasılıklı Makina Güvenilirlik } \\
\text { Değerlendirmesi (OMGD) stratejisi sunulmuştur. }\end{array}$ \\
\hline
\end{tabular}


Hemen her alanda kullanılan veri madenciliği yöntemlerinin denizcilik alanında da, farklı konu başlıklarında uygulandığ 1 ve yöntemin doğasına uygun (tanımlayıcı ve tahmin edici) sonuçların elde edildiği görülmektedir. Yazın taraması sonucu elde edilen değişkenlerle, kaza raporlarının içerik analizleri sonucu oluşturulan verilerin kodlanması sonrası, verilerin işlenmesi ve değiş̧kenler arası iliş̧ilerin tespiti için veri madenciliği programlarından Waikato Üniversitesinde Java programlama diliyle geliştirilmiş olan WEKA (Waikato Environment for Knowledge Analysis) programının 3.9.2. numaralı versiyonu kullanılmıştır. WEKA; bilgisayar bilimlerinin önemli konularından birisi olan makine öğrenmesi (machine language) konusunda kullanılan paketlerden birisinin ismidir (https://www.cs. waikato.ac.nz/ml/weka/). Bu çalışmada verilerin kodlanması ve WEKA programına girişlerinin yapılması sonrası değişkenler arası ilişki ve kazaların oluş sebeplerinde bu değişkenlerin birlikteliklerinin incelenmesi için apriori algoritması ile birliktelik kuralı analizi (Association Rules) uygulaması yapılmıştır.

\section{BULGULAR}

Türk karasularında 2007-2017 yılları arasında meydana gelen ve "AAKKM" ye raporlanmış kazalar incelenmiştir. İçerik analizi ile başlayan süreçte elde edilen veriler, analiz yönteminde kullanılacak olan veri madenciliği için bilgi keşfine uygun bir şekilde; temizleme, bütünleştirme, indirgeme ve dönüştürme sürecinden geçirilerek "WEKA" programına uygun format haline getirilirmiştir. Kazaların yıllara göre dağılımı Tablo 4 'te sunulmuştur.

Tablo 4. Kazaların Yıllara Göre Dağılımı

\begin{tabular}{cllllllllllll}
\hline $\begin{array}{c}\text { Kaza } \\
\text { Yllı }\end{array}$ & $\mathbf{2 0 0 7}$ & $\mathbf{2 0 0 8}$ & $\mathbf{2 0 0 9}$ & $\mathbf{2 0 1 0}$ & $\mathbf{2 0 1 1}$ & $\mathbf{2 0 1 2}$ & $\mathbf{2 0 1 3}$ & $\mathbf{2 0 1 4}$ & $\mathbf{2 0 1 5}$ & $\mathbf{2 0 1 6}$ & $\mathbf{2 0 1 7}$ & Toplam \\
\hline $\mathrm{n}$ & 55 & 127 & 93 & 115 & 69 & 67 & 52 & 50 & 40 & 37 & 33 & 738 \\
\hline$\%$ & 7,45 & 17,21 & 12,6 & 15,58 & 9,35 & 9,08 & 7,05 & 6,78 & 5,42 & 5,01 & 4,47 & 100 \\
\hline
\end{tabular}

Y1llara dağılımına bakıldığında Türk karasularında meydana raporlu kazaların sayısında ilk yıllara göre ciddi bir azalma görülmektedir. 2008 ve 2010 yıllarında en yüksek seviyelerde seyreden kaza sayılarının daha sonraki yıllarda giderek azalmasında, yaşanan ekonomik krizden ötürü azalan gemi trafiğinin de etkisi olduğu söylenilebilir. Bununla birlikte ticaretin yavaşlamasıyla kondisyonu düşük, yaşlı ve yıpranmış gemiler yerine daha yeni ve iyi durumdaki gemilerin ihtiyacı karşılamasından ötürü nispeten azalan deniz trafiğini daha iyi durumdaki gemilerin oluşturması olabilir. İçerik analizi ile elde edilen bulgulardan bazıları şu şekildedir. En fazla kaza 2008 yılında Aralık ve Ocak aylarında gerçekleştiği götülmüştür. İnşa tarihi açısından 1977 yapımı gemiler ilk sırada yer alırken, en çok kaza 12:00-15:59 saatleri arasında, en az kaza ise 04:00-07:59 saatleri arasında yaşanmıştır. Bununla birlikte kazaya karışan gemilerin kayıtl olduğu klas kuruluşlarından başlıcalarını ise dünyaca tanınmış DNV-GL (89 gemi), TL (87 gemi), BV (74 gemi), ABS (47 gemi) gibi önemli kurumlar oluşturmaktadır.

Yaşandığı zaman dilimi bakımından kazalar, 19 farklı zaman aralığında değerlendirilmiştir. Bu bölümlendirme, vardiya başlangıçlarının ve bitişlerinin ilk ve son yarım saatinin "adaptasyon ve motivasyonu engelleyebileceği ihtimali göz önünde tutularak yapılmıştır. Toplam kazalardan 19'unun saati belirtilmemiştir. Saat 07:30-19:29 arasında yaşanmış ve "gün içiı" şeklinde ifade edebileceğimiz zaman aralığında gerçekleşen kaza say1s1 374 adet, 19:30-07:29 saatleri arasında "gece" şeklinde ifade edebileceğimiz zaman aralığında gerçekleşen kaza sayısı ise 345 olarak karşımıza çıkmaktadır. Cockroft (1982), kısıtlı görüşte yaşanan kazalarda fark edilebilir bir değişiklik olmamakla beraber iyi görüş durumunda gece yaşanan kazaların gündüz yaşanan kazalara oranla yaklaşık üç kat fazla gerçekleştiği sonucuna ulaşmıştır (Akten, 2006: 275). Akten'e göre ise İstanbul Boğazı için yaşanan kazalarda gece yaşanan kaza sayısının gündüze oranla neredeyse iki katı fazlalık tespit 
edilmiş (Akten, 2006:275) ve bu bağlamda açık görüş koşullarında karanlık, kazalar için en önemli etkilerinden biridir (Akten, 2006) yönündeki ifadelerden farklı olarak, bu çalışmada gün içerisinde yaşanan kazaların gece yaşanan kazalardan daha fazla olabileceği tespit edilmiştir. Bununla birlikte gerçekleşen kazalarda "vardiyaların ilk yarım saati ile son yarım saati" şeklinde ifade edebileceğimiz zaman diliminde olușan kaza adedi 222 ve 719 kaza içindeki oranı ise \%30.9 dur.

Uygulama için hazırlanan veri seti birliktelik kuralı analizi çerçevesinde değerlendirilmiştir.
27 değişkenle oluşturulan ve WEKA'ya uygun halde kodlanan veriler apriori algoritmasi ile birliktelik kuralı analizi yapılmış, çıkan sonuç ve birliktelikler aşağıdaki tablolarda gösterilmiştir. Bunun için algoritmada kullanılan minimum destek değeri \%10 alınarak, destek (support), ilgi (lift), doğruluk (confidence) değerleri çeşitli kombinasyonlar ile denenerek en iyi kural ve birliktelik oranları bulunmaya çalışılmıştır. $\mathrm{Bu}$ bağlamda en iyi 50 birliktelik kuralı için ilgi (lift) değeriyle elde edilmiş ve çıktı olarak 13 değişken arasında birliktelik ve ilişki bulunmuştur. Kullanılan parametreler Tablo 5'te belirtilmiştir.

Tablo 5. Birliktelik Kuralı Analizinde Kullanılan Parametreler

\begin{tabular}{cc}
\hline Döngü Sayısı & 18 \\
\hline Delta & 0.05 \\
\hline Üst Minimum Destek & $\% 100$ \\
\hline Alt Minimum Destek & $\% 10$ \\
\hline Minimum Metrik & $1.1 / 2.0 / 3.0 / 4.0 / 5.0 / 5.5 / 5.7$ \\
\hline Kural & $10 / 25 / 50$ \\
\hline
\end{tabular}

Şekil 3'te ise kazaların meydana gelmesinde etken olan ve yaşanan kazalar neticesinde ortaya çıkan, kaza içerik analizi neticesinde elde edilen
27 değişkenin oluşturduğu liste ile uygulanan birliktelik kuralı sonucu ortaya çıkan değișkenler sunulmuştur.

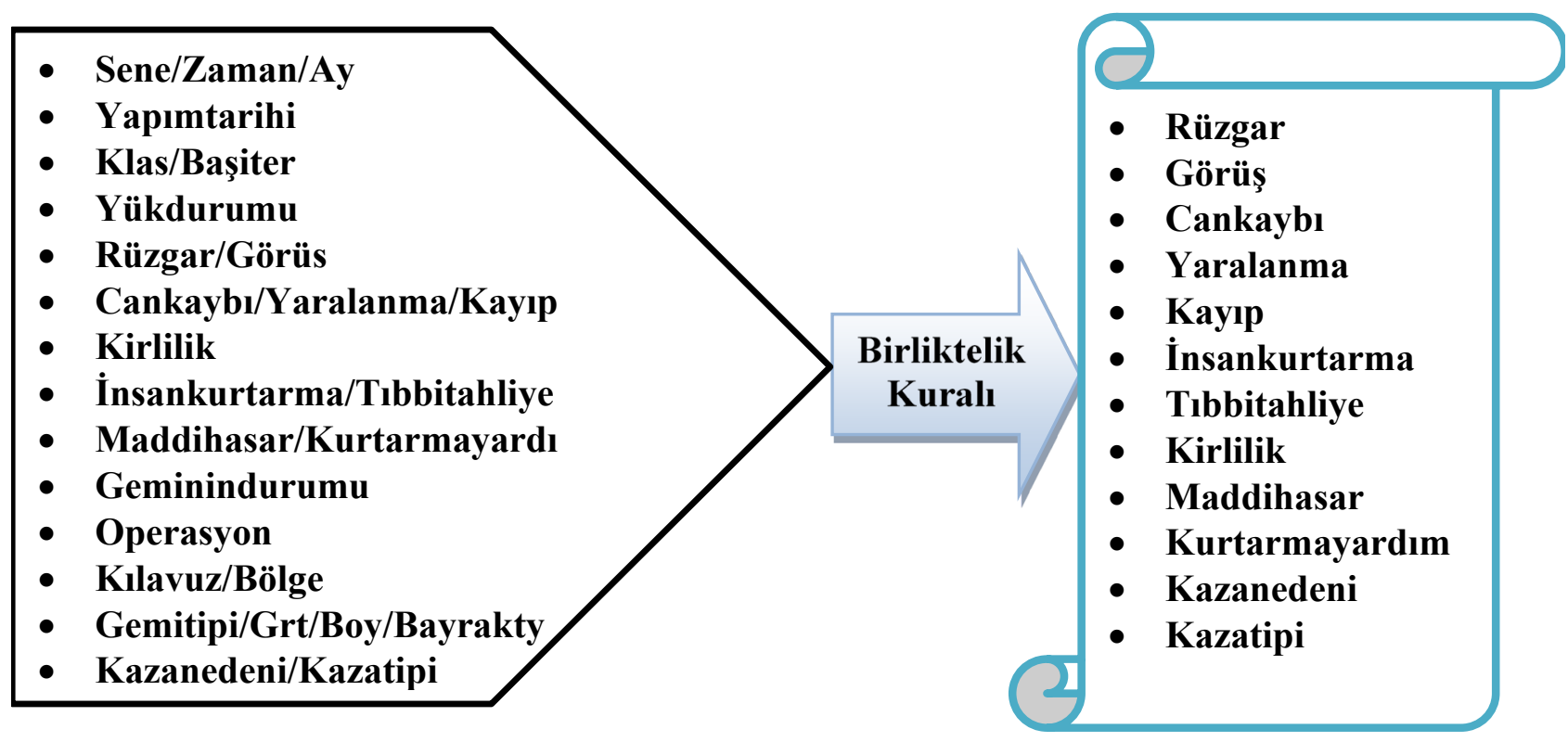

Şekil 3. Birliktelik Kuralı Girdi ve Çıktıları 
Birliktelik kuralı analizinde girdiler sonucu oluşan çıktı ve birliktelik ilişkileri aşağıdaki tablolarda gösterilmektedir. Tablolarda apriori algoritmasinda \%10 olarak ayarlanan destek değerine ulaşıncaya kadar bulunan birlikteliklerden en yüksek değere sahip $15^{\prime}$ 'li ilişsi kümeleri görülmekte ve uygun kümeler kendi içlerinde yorumlanmaktadır.

Tablo 6. Birliktelik Kuralı Nitelikler Kümesi (10) 15'li Kümeler.

\begin{tabular}{|c|c|c|c|}
\hline No & Nitelikler Kümesi (10): 15/10660 & Frekans & Destek \\
\hline 1 & $\begin{array}{l}\text { başiter }=2 \text { görüs }=1 \text { cankaybı }=2 \text { yaralanma }=2 \text { kayıp }=2 \text { insankurtarma }=2 \\
\text { tıbbitahliye }=2 \text { kirlilik }=2 \text { kılavz }=2 \text { gemitipi }=1\end{array}$ & 241 & 0.3265 \\
\hline 2 & $\begin{array}{l}\text { rüzgar }=1 \text { görüs }=1 \text { cankaybı }=2 \text { yaralanma }=2 \text { kayıp }=2 \text { insankurtarma }=2 \\
\text { tıbitahliye }=2 \text { kirlilik }=2 \text { kılavz }=2 \text { gemitipi }=1\end{array}$ & 240 & 0.3252 \\
\hline 3 & $\begin{array}{l}\text { başiter }=2 \text { rüzgar }=1 \text { görüs }=1 \text { cankayb } 1=2 \text { yaralanma }=2 \text { kayıp }=2 \\
\text { insankurtarma }=2 \text { tıbbitahliye }=2 \text { kirlilik }=2 \text { k1lavz }=2\end{array}$ & 225 & 0.3048 \\
\hline 4 & $\begin{array}{l}\text { başiter }=2 \text { rüzgar }=1 \text { görüs }=1 \text { cankaybı }=2 \text { yaralanma }=2 \text { kayıp }=2 \\
\text { insankurtarma }=2 \text { tıbbitahliye }=2 \text { kirlilik }=2 \text { gemitipi }=1\end{array}$ & 216 & 0.2926 \\
\hline 5 & $\begin{array}{l}\text { görüs }=1 \text { cankayb1 }=2 \text { yaralanma }=2 \text { kayıp }=2 \text { insankurtarma }=2 \text { tıbbitahliye }=2 \\
\text { kirlilik }=2 \text { k1lavz }=2 \text { gemitipi }=1 \text { bayrakty }=2\end{array}$ & 216 & 0.2926 \\
\hline 6 & $\begin{array}{l}\text { başiter }=2 \text { rüzgar }=1 \text { görüs }=1 \text { cankayb1 }=2 \text { yaralanma }=2 \text { kayıp }=2 \\
\text { insankurtarma }=2 \text { kirlilik }=2 \text { k1lavz }=2 \text { gemitipi }=1\end{array}$ & 205 & 0.2777 \\
\hline 7 & $\begin{array}{l}\text { görüs }=1 \text { cankaybı }=2 \text { yaralanma }=2 \text { kayıp }=2 \text { insankurtarma }=2 \text { tıbbitahliye }=2 \\
\text { kirlilik }=2 \text { maddihasar }=2 \text { k1lavz }=2 \text { gemitipi }=1\end{array}$ & 204 & 0.2764 \\
\hline 8 & $\begin{array}{l}\text { görüs }=1 \text { cankayb } 1=2 \text { yaralanma }=2 \text { kayıp }=2 \text { insankurtarma }=2 \text { tıbbitahliye }=2 \\
\text { kirlilik }=2 \text { geminindurumu }=1 \text { k1lavz }=2 \text { gemitipi }=1\end{array}$ & 204 & 0.2764 \\
\hline 9 & $\begin{array}{l}\text { başiter }=2 \text { rüzgar }=1 \text { görüs }=1 \text { cankaybı }=2 \text { yaralanma }=2 \text { kayıp }=2 \\
\text { tıbbitahliye }=2 \text { kirlilik }=2 \text { kılavz }=2 \text { gemitipi }=1\end{array}$ & 201 & 0.2723 \\
\hline 10 & $\begin{array}{l}\text { rüzgar }=1 \text { görüs }=1 \text { cankaybı }=2 \text { yaralanma }=2 \text { kayıp }=2 \text { insankurtarma }=2 \\
\text { tıbitahliye }=2 \text { kirlilik }=2 \text { maddihasar }=2 \text { k1lavz }=2\end{array}$ & 201 & 0.2723 \\
\hline 11 & $\begin{array}{l}\text { rüzgar }=1 \text { görüs }=1 \text { cankaybı }=2 \text { yaralanma }=2 \text { kayıp }=2 \text { insankurtarma }=2 \\
\text { tıbbitahliye }=2 \text { kirlilik }=2 \text { gemitipi }=1 \text { bayrakty }=2\end{array}$ & 196 & 0.2655 \\
\hline 12 & $\begin{array}{l}\text { rüzgar }=1 \text { görüs }=1 \text { cankaybı }=2 \text { yaralanma }=2 \text { kayıp }=2 \text { insankurtarma }=2 \\
\text { tıbbitahliye }=2 \text { kirlilik }=2 \text { k1lavz }=2 \text { bayrakty }=2\end{array}$ & 195 & 0.2642 \\
\hline 13 & $\begin{array}{l}\text { görüs }=1 \text { cankaybı }=2 \text { yaralanma }=2 \text { kayıp }=2 \text { insankurtarma }=2 \text { tıbbitahliye }=2 \\
\text { kirlilik }=2 \text { kurtarmayardım }=3 \text { kılavz }=2 \text { gemitipi }=1\end{array}$ & 195 & 0.2642 \\
\hline 14 & $\begin{array}{l}\text { başiter }=2 \text { rüzgar }=1 \text { görüs }=1 \text { yaralanma }=2 \text { kayıp }=2 \text { insankurtarma }=2 \\
\text { tıbbitahliye }=2 \text { kirlilik }=2 \text { kılavz }=2 \text { gemitipi }=1\end{array}$ & 194 & 0.2628 \\
\hline 15 & $\begin{array}{l}\text { rüzgar }=1 \text { görüs }=1 \text { cankaybı }=2 \text { yaralanma }=2 \text { kayıp }=2 \text { insankurtarma }=2 \\
\text { tıbbitahliye }=2 \text { kirlilik }=2 \text { geminindurumu }=1 \text { k1lavz }=2\end{array}$ & 192 & 0.2601 \\
\hline
\end{tabular}

10'lu birliktelikler içinde 1. ve 11. suradaki birliktelikleri incelediğimizde 11. Siradaki birlikteliğin içinde rüzgâr=1 (sakin hava) ve bayrak $=2$ (yabancı bayrak) değişkenleri yerine başiter=2 (baş iter yok) ve kılavuz=2 (k1lavuz kaptan yok) değişkenleri dâhil olduğunda, gemitipi=1 (kuru dökme yük gemileri) için kaza birlikteliklerinde frekans değeri 196'dan 241'e, destek değerleri ise 0.265 'ten 0.326'ya yükselmiş, baş iter ve kılavuz kaptan yokluğunun kaza artışında çok ciddi etken olduğu görülmüştür. Bununla birlikte 1. ve 2. siradaki birlikteliklere baktığımızdaysa gemitipi=1 (kuru dökme yük gemileri) için rüzgâr=1 (sakin hava) değişkeni yerini başiter=2 (baş iter yok) aldığında kaza frekans değerinde çok çok küçük bir değişim görülmektedir. Buradan hareketle birliktelik analizine göre gemitipi=1 (kuru dökme yük gemileri) için kılavuz kaptan olmayışının, kaza oluşumunda gemi teknik donanımı açısından baş iteri olmamasından daha fazla etkili olduğu söylenilebilir. 8 ve 15 . siradaki birliktelikleri değerlendirdiğimizde ise gemidurumu $=1$ (hizmet dış1 gemi) için rüzgâr $=1$ (sakin hava) değişkeni yerine gemitipi=1 (kuru/ dökme yük gemileri) geldiğinde kaza birlikteliklerinde 192'den 204'e yükselmiş destek değeri ise 0.2601 'den 0.2764 'e çıkmıştır. $\mathrm{Bu}$ bağlamda gemi tipinin kaza oluşumunda önemli bir yer edindiği söylenilebilir. 
Tablo 7. Birliktelik Kuralı Nitelikler Kümesi(11) 15'li Kümeler.

\begin{tabular}{|c|c|c|c|}
\hline No & Nitelikler Kümesi (11): 15/2492 & Frekans & Destek \\
\hline 1 & $\begin{array}{l}\text { başiter }=2 \text { rüzgar }=1 \text { görüs }=1 \text { cankayb } 1=2 \text { yaralanma }=2 \text { kayıp }=2 \\
\text { insankurtarma }=2 \text { tıbitahliye }=2 \text { kirlilik }=2 \text { kllavz }=2 \text { gemitipi }=1\end{array}$ & 186 & 0.2520 \\
\hline 2 & $\begin{array}{l}\text { rüzgar }=1 \text { görüs }=1 \text { cankaybı }=2 \text { yaralanma }=2 \text { kayıp }=2 \text { insankurtarma }=2 \\
\text { tıbbitahliye }=2 \text { kirlilik }=2 \text { kılavz }=2 \text { gemitipi }=1 \text { bayrakty }=2\end{array}$ & 165 & 0.2235 \\
\hline 3 & $\begin{array}{l}\text { rüzgar }=1 \text { görüs }=1 \text { cankaybı }=2 \text { yaralanma }=2 \text { kayıp }=2 \text { insankurtarma }=2 \\
\text { tıbbitahliye }=2 \text { kirlilik }=2 \text { maddihasar }=2 \text { k1lavz }=2 \text { gemitipi }=1\end{array}$ & 163 & 0.2208 \\
\hline 4 & $\begin{array}{l}\text { başiter }=2 \text { görüs }=1 \text { cankaybı }=2 \text { yaralanma }=2 \text { kayıp }=2 \text { insankurtarma }=2 \\
\text { tıbitahliye }=2 \text { kirlilik }=2 \text { geminindurumu }=1 \text { k1lavz }=2 \text { gemitipi }=1\end{array}$ & 161 & 0.2181 \\
\hline 5 & $\begin{array}{l}\text { görüs }=1 \text { cankaybı }=2 \text { yaralanma }=2 \text { kayıp }=2 \text { insankurtarma }=2 \text { tıbbitahliye }=2 \\
\text { kirlilik }=2 \text { geminindurumu }=1 \text { k1lavz }=2 \text { gemitipi }=1 \text { bayrakty }=2\end{array}$ & 161 & 0.2181 \\
\hline 6 & $\begin{array}{l}\text { başiter }=2 \text { görüs }=1 \text { cankaybı }=2 \text { yaralanma }=2 \text { kayıp }=2 \text { insankurtarma }=2 \\
\text { tıbbitahliye }=2 \text { kirlilik }=2 \text { kılavz }=2 \text { gemitipi }=1 \text { bayrakty }=2\end{array}$ & 159 & 0.2154 \\
\hline 7 & $\begin{array}{l}\text { rüzgar }=1 \text { görüs }=1 \text { cankaybı }=2 \text { yaralanma }=2 \text { kayıp }=2 \text { insankurtarma }=2 \\
\text { tıbbitahliye }=2 \text { kirlilik }=2 \text { geminindurumu }=1 \text { kllavz }=2 \text { gemitipi }=1\end{array}$ & 159 & 0.2154 \\
\hline 8 & $\begin{array}{l}\text { başiter }=2 \text { görüs }=1 \text { cankaybı }=2 \text { yaralanma }=2 \text { kayıp }=2 \text { insankurtarma }=2 \\
\text { tıbitahliye }=2 \text { kirlilik }=2 \text { maddihasar }=2 \text { kılavz }=2 \text { gemitipi }=1\end{array}$ & 153 & 0.2073 \\
\hline 9 & $\begin{array}{l}\text { başiter }=2 \text { görüs }=1 \text { cankaybı }=2 \text { yaralanma }=2 \text { kayıp }=2 \text { insankurtarma }=2 \\
\text { tıbitahliye }=2 \text { kirlilik }=2 \text { kurtarmayardım }=3 \text { k1lavz }=2 \text { gemitipi }=1\end{array}$ & 153 & 0.2073 \\
\hline 10 & $\begin{array}{l}\text { başiter }=2 \text { görüs }=1 \text { cankaybı }=2 \text { yaralanma }=2 \text { kayıp }=2 \text { insankurtarma }=2 \\
\text { tıbbitahliye }=2 \text { kirlilik }=2 \text { kılavz }=2 \text { bölge }=3 \text { gemitipi }=1\end{array}$ & 147 & 0.1991 \\
\hline 11 & $\begin{array}{l}\text { rüzgar }=1 \text { görüs }=1 \text { cankaybı }=2 \text { yaralanma }=2 \text { kayıp }=2 \text { insankurtarma }=2 \\
\text { tıbbitahliye }=2 \text { kirlilik }=2 \text { kurtarmayardım }=3 \text { k1lavz }=2 \text { gemitipi }=1\end{array}$ & 147 & 0.1991 \\
\hline 12 & $\begin{array}{l}\text { görüs }=1 \text { cankaybı }=2 \text { yaralanma }=2 \text { kayıp }=2 \text { insankurtarma }=2 \text { tıbbitahliye }=2 \\
\text { kirlilik }=2 \text { maddihasar }=2 \text { geminindurumu }=1 \text { k1lavz }=2 \text { gemitipi }=1\end{array}$ & 146 & 0.1978 \\
\hline 13 & $\begin{array}{l}\text { görüs }=1 \text { cankayb } 1=2 \text { yaralanma }=2 \text { kayıp }=2 \text { insankurtarma }=2 \text { tıbbitahliye }=2 \\
\text { kirlilik }=2 \text { maddihasar }=2 \mathrm{k} \text { lavz }=2 \text { gemitip }=1 \text { bayrakty }=2\end{array}$ & 146 & 0.1978 \\
\hline 14 & $\begin{array}{l}\text { başiter }=2 \text { rüzgar }=1 \text { görüs }=1 \text { cankaybı }=2 \text { yaralanma }=2 \text { kayıp }=2 \\
\text { insankurtarma }=2 \text { tıbbitahliye }=2 \text { kirlilik }=2 \text { kurtarmayardım }=3 \text { kılavz }=2\end{array}$ & 144 & 0.1951 \\
\hline 15 & $\begin{array}{l}\text { rüzgar }=1 \text { görüs }=1 \text { cankaybı }=2 \text { yaralanma }=2 \text { kayıp }=2 \text { insankurtarma }=2 \\
\text { tıbitahliye }=2 \text { kirlilik }=2 \text { geminindurumu }=1 \text { k1lavz }=2 \text { bayrakty }=2\end{array}$ & 144 & 0.1951 \\
\hline
\end{tabular}

11'li nitelikler kümesinde bir ve iki numaralı birliktelikleri incelediğimizde, ilk iki birliktelikte gemitipi=1 (kuru/dökme yük gemisi) için k1lavuz=2 (kılavuz kaptan yok) koşulunda diğer değişkenler de sabit kalmak koşuluyla bayrak=2 (yabancı bayrak) değişkeni yerine başiter=2 (baş iter yok) değişkeni geldiğinde kaza sayısında ciddi bir değişim yaşanarak 165 ten 186 ya destek değerininse 0.2235 'ten 0.2520 'ye yükseldiği, baş iter yokluğunun kaza artışında önemli rol üstlendiği gözlemlenmektedir. Dördüncü ve beşinci sıralardaki birliktelikler incelendiğinde ise diğer değişkenler sabit kalmak koşuluyla bayrak=2 (yabancı bayrak) değişkeni yerine ilk iki sıradaki değişkenlerde olduğu gibi (kılavuzsuz kuru/dökme yük gemileri için) başiter=2 (baş iter yok) değişkeni geldiğinde kaza frekans değeri sabit kalmış baş iterin olmayışı herhangi bir etki sunmamıştır. Burada dikkat çeken detay ise birliktelikler kümesine geminindurumu $=1$ (hizmet dişı gemi) değişkeninin dâhil olmasıdır. $\mathrm{Bu}$ bağlamda geminin baş iterle donatılmasının sadece faaliyetteki gemilerin kazaya karışma riskini azalttığı söylenebilir. 
Tablo 8. Birliktelik Kuralı Nitelikler Kümesi (12) 15'li Kümeler.

\begin{tabular}{|c|c|c|c|}
\hline No & Nitelikler Kümesi (12): 15/318 & Frekans & Destek \\
\hline 1 & $\begin{array}{l}\text { başiter }=2 \text { görüs }=1 \text { cankaybı }=2 \text { yaralanma }=2 \text { kayıp }=2 \text { insankurtarma }=2 \\
\text { tıbitahliye }=2 \text { kirlilik }=2 \text { geminindurumu }=1 \text { k1lavz }=2 \text { gemitipi }=1 \\
\text { bayrakty }=2\end{array}$ & 125 & 0.1963 \\
\hline 2 & $\begin{array}{l}\text { rüzgar }=1 \text { görüs }=1 \text { cankaybı }=2 \text { yaralanma }=2 \text { kayıp }=2 \text { insankurtarma }=2 \\
\text { tıbitahliye }=2 \text { kirlilik }=2 \text { geminindurumu }=1 \text { k1lavz }=2 \text { gemitipi }=1 \\
\text { bayrakty }=2\end{array}$ & 124 & 0.1680 \\
\hline 3 & $\begin{array}{l}\text { başiter }=2 \text { rüzgar }=1 \text { görüs }=1 \text { cankayb } 1=2 \text { yaralanma }=2 \text { kayıp }=2 \\
\text { insankurtarma }=2 \text { tıbbitahliye }=2 \text { kirlilik }=2 \text { geminindurumu }=1 \text { kılavz=2 } \\
\text { gemitipi }=1\end{array}$ & 123 & 0.1666 \\
\hline 4 & $\begin{array}{l}\text { başiter }=2 \text { rüzgar }=1 \text { görüs }=1 \text { cankaybı }=2 \text { yaralanma }=2 \text { kayıp }=2 \\
\text { insankurtarma }=2 \text { tıbbitahliye }=2 \text { kirlilik }=2 \text { kılavz }=2 \text { gemitipi }=1 \text { bayrakty }=2\end{array}$ & 122 & 0.1653 \\
\hline 5 & $\begin{array}{l}\text { başiter }=2 \text { rüzgar }=1 \text { görüs }=1 \text { cankaybı }=2 \text { yaralanma }=2 \text { kayıp }=2 \\
\text { insankurtarma }=2 \text { tıbbitahliye }=2 \text { kirlilik }=2 \text { maddihasar }=2 \text { kılavz }=2 \\
\text { gemitipi }=1\end{array}$ & 121 & 0.1639 \\
\hline 6 & $\begin{array}{l}\text { başiter }=2 \text { rüzgar }=1 \text { görüs }=1 \text { cankaybı }=2 \text { yaralanma }=2 \text { kayıp }=2 \\
\text { insankurtarma }=2 \text { tıbbitahliye }=2 \text { kirlilik }=2 \text { kurtarmayardım }=3 \text { kılavz=2 } \\
\text { gemitipi }=1\end{array}$ & 117 & 0.1585 \\
\hline 7 & $\begin{array}{l}\text { görüs }=1 \text { cankayb } 1=2 \text { yaralanma }=2 \text { kayıp }=2 \text { insankurtarma }=2 \text { tıbbitahliye }=2 \\
\text { kirlilik }=2 \text { maddihasar }=2 \text { geminindurumu }=1 \text { k1lavz }=2 \text { gemitipi }=1 \\
\text { bayrakty }=2\end{array}$ & 117 & 0.1585 \\
\hline 8 & $\begin{array}{l}\text { rüzgar }=1 \text { görüs }=1 \text { cankayb1 }=2 \text { yaralanma }=2 \text { kayıp }=2 \text { insankurtarma }=2 \\
\text { tıbitahliye }=2 \text { kirlilik }=2 \text { maddihasar }=2 \text { geminindurumu }=1 \text { kılavz }=2 \\
\text { gemitipi }=1\end{array}$ & 116 & 0.1571 \\
\hline 9 & $\begin{array}{l}\text { rüzgar }=1 \text { görüs }=1 \text { cankaybı }=2 \text { yaralanma }=2 \text { kayıp }=2 \text { insankurtarma }=2 \\
\text { tıbbitahliye }=2 \text { kirlilik }=2 \text { maddihasar }=2 \text { k1lavz }=2 \text { gemitipi }=1 \text { bayrakty }=2\end{array}$ & 114 & 0.1544 \\
\hline 10 & $\begin{array}{l}\text { başiter }=2 \text { görüs }=1 \text { cankaybı }=2 \text { yaralanma }=2 \text { kayıp }=2 \text { insankurtarma }=2 \\
\text { tıbitahliye }=2 \text { kirlilik }=2 \text { maddihasar }=2 \text { geminindurumu }=1 \text { kılavz }=2 \\
\text { gemitipi }=1\end{array}$ & 110 & 0.1490 \\
\hline 11 & $\begin{array}{l}\text { başiter }=2 \text { rüzgar }=1 \text { görüs }=1 \text { cankaybı }=2 \text { yaralanma }=2 \text { kayıp }=2 \\
\text { insankurtarma }=2 \text { tıbbitahliye }=2 \text { kirlilik }=2 \text { kılavz }=2 \text { bölge }=3 \text { gemitipi }=1\end{array}$ & 108 & 0.1463 \\
\hline 12 & $\begin{array}{l}\text { başiter }=2 \text { görüs }=1 \text { cankayb } 1=2 \text { yaralanma }=2 \text { kayıp }=2 \text { insankurtarma }=2 \\
\text { tıbbitahliye }=2 \text { kirlilik }=2 \text { maddihasar }=2 \text { kılavz }=2 \text { gemitipi }=1 \text { bayrakty }=2\end{array}$ & 106 & 0.1436 \\
\hline 13 & $\begin{array}{l}\text { başiter }=2 \text { görüs }=1 \text { cankaybı }=2 \text { yaralanma }=2 \text { kayıp }=2 \text { insankurtarma }=2 \\
\text { tıbbitahliye }=2 \text { kirlilik }=2 \text { kurtarmayardım }=3 \text { kılavz }=2 \text { bölge }=3 \text { gemitipi }=1\end{array}$ & 106 & 0.1436 \\
\hline 14 & $\begin{array}{l}\text { rüzgar }=1 \text { görüs }=1 \text { cankaybı }=2 \text { yaralanma }=2 \text { kayıp }=2 \text { insankurtarma }=2 \\
\text { tıbitahliye }=2 \text { kirlilik }=2 \text { maddihasar }=2 \text { geminindurumu }=1 \text { kılavz }=2 \\
\text { bayrakty }=2\end{array}$ & 106 & 0.1436 \\
\hline 15 & $\begin{array}{l}\text { rüzgar }=1 \text { görüs }=1 \text { cankaybı }=2 \text { yaralanma }=2 \text { kayıp }=2 \text { insankurtarma }=2 \\
\text { tıbbitahliye }=2 \text { kirlilik }=2 \text { maddihasar }=2 \text { operasyon }=1 \text { kılavz }=2 \text { gemitipi }=1\end{array}$ & 106 & 0.1436 \\
\hline
\end{tabular}

12'li birliktelikler değerlendirildiğinde ilk sıray1 alan birlikteliğin frekans değeri 125, destek değeri ise 0.169 dur. 9. Siradaki birliktelikte ise frekans değeri 114 ve destek değeri 0.154 olarak görülmektedir. Bu iki birliktelik grupları kendi aralarında karşılaştırıldığında, 9. sıradaki maddihasar-2 (maddi hasar raporlanmamış) ve rüzgâr-1 (rüzgâr yok) değişkenleri yerine 1 . sıradaki geminindurumu-1 (gemi kullanım dışı) ve başiter-2 (baş iter yok) değişkenleri geldiğinde frekans değerinde gözle görülür bir artış yaşanmıştır. Bu durumda gemitipi=1 (kuru/ dökme yük gemisi) için baş iterin olmayışı kaza artışında önemli bir etken olarak görülmektedir. Gruplar genel anlamda değerlendirildiğinde, göze çarpan değişkenlerden; bölge-3 (Marmara denizi-İstanbul boğazı), operasyon-1 (seyir), bayrak-2 (yb. bayrak) değişkenlerinin olduğu birlikteliklerde kaza frekans değeri 106, destek değeri 0.143 iken birlikteliklere, gemitipi-1 (kuru/dökme yük) ve kılavuz-2 (kılavuz kaptan yok) dâhil olduğunda kaza frekansının 125 ve destek değerinin 0.169 olarak ciddi şekilde $\operatorname{arttığ} 1$ gözlemlenmiştir. 
Tablo 9. Birliktelik Kuralı Nitelikler Kümesi (13) 15'li Kümeler.

\begin{tabular}{|c|c|c|c|}
\hline No & Nitelikler Kümesi (13): 15/15 & Frekans & Destek \\
\hline 1 & $\begin{array}{l}\text { başiter }=2 \text { rüzgar }=1 \text { görüs }=1 \text { cankayb } 1=2 \text { yaralanma }=2 \text { kayıp }=2 \text { insankurtarma }=2 \\
\text { tıbbitahliye }=2 \text { kirlilik }=2 \text { geminindurumu }=1 \text { kılavz }=2 \text { gemitipi }=1 \text { bayrakty }=2\end{array}$ & 94 & 0.1273 \\
\hline 2 & $\begin{array}{l}\text { rüzgar }=1 \text { görüs }=1 \text { cankaybı }=2 \text { yaralanma }=2 \text { kayıp }=2 \text { insankurtarma }=2 \\
\text { tıbbitahliye }=2 \text { kirlilik }=2 \text { maddihasar }=2 \text { geminindurumu }=1 \text { kılavz }=2 \text { gemitipi }=1 \\
\text { bayrakty }=2\end{array}$ & 91 & 0.1233 \\
\hline 3 & $\begin{array}{l}\text { başiter }=2 \text { görüs }=1 \text { cankaybı }=2 \text { yaralanma }=2 \text { kayıp }=2 \text { insankurtarma }=2 \\
\text { tıbbitahliye }=2 \text { kirlilik }=2 \text { maddihasar }=2 \text { geminindurumu }=1 \text { kılavz }=2 \text { gemitipi }=1 \\
\text { bayrakty }=2\end{array}$ & 87 & 0.1178 \\
\hline 4 & $\begin{array}{l}\text { başiter }=2 \text { rüzgar }=1 \text { görüs }=1 \text { cankaybı }=2 \text { yaralanma }=2 \text { kayıp }=2 \text { insankurtarma }=2 \\
\text { tıbbitahliye }=2 \text { kirlilik }=2 \text { maddihasar }=2 \text { geminindurumu }=1 \text { kllavz }=2 \text { gemitipi }=1\end{array}$ & 85 & 0.1151 \\
\hline 5 & $\begin{array}{l}\text { başiter }=2 \text { rüzgar }=1 \text { görüs }=1 \text { cankaybı }=2 \text { yaralanma }=2 \text { kayıp }=2 \text { insankurtarma }=2 \\
\text { tıbbitahliye }=2 \text { kirlilik }=2 \text { maddihasar }=2 \text { kllavz }=2 \text { gemitipi }=1 \text { bayrakty }=2\end{array}$ & 81 & 0.1097 \\
\hline 6 & $\begin{array}{l}\text { rüzgar }=1 \text { görüs }=1 \text { cankaybı }=2 \text { yaralanma }=2 \text { kayıp }=2 \text { insankurtarma }=2 \\
\text { tıbbitahliye }=2 \text { kirlilik }=2 \text { maddihasar }=2 \text { geminindurumu }=1 \text { operasyon }=1 \text { kılavz }=2 \\
\text { gemitipi }=1\end{array}$ & 80 & 0.1084 \\
\hline 7 & $\begin{array}{l}\text { rüzgar }=1 \text { görüs }=1 \text { cankaybı }=2 \text { yaralanma }=2 \text { kayıp }=2 \text { insankurtarma }=2 \\
\text { tıbbitahliye }=2 \text { kirlilik }=2 \text { geminindurumu }=1 \text { operasyon }=1 \text { kılavz }=2 \text { gemitipi }=1 \\
\text { bayrakty }=2\end{array}$ & 80 & 0.1084 \\
\hline 8 & $\begin{array}{l}\text { başiter }=2 \text { rüzgar }=1 \text { görüs }=1 \text { cankaybı }=2 \text { yaralanma }=2 \text { kayıp }=2 \text { insankurtarma }=2 \\
\text { tıbbitahliye }=2 \text { kirlilik }=2 \text { geminindurumu }=1 \text { operasyon }=1 \text { kllavz }=2 \text { gemitipi }=1\end{array}$ & 78 & 0.1056 \\
\hline 9 & $\begin{array}{l}\text { başiter }=2 \text { yükdurumu }=1 \text { rüzgar }=1 \text { görüs }=1 \text { cankayb } 1=2 \text { yaralanma }=2 \text { kayıp }=2 \\
\text { insankurtarma }=2 \text { tıbbitahliye }=2 \text { kirlilik }=2 \text { geminindurumu }=1 \\
\text { k1lavz }=2 \text { gemitipi }=1\end{array}$ & 77 & 0.1043 \\
\hline 10 & $\begin{array}{l}\text { başiter }=2 \text { rüzgar }=1 \text { görüs }=1 \text { cankaybı }=2 \text { yaralanma }=2 \text { kayıp }=2 \text { insankurtarma }=2 \\
\text { tıbbitahliye }=2 \text { kirlilik }=2 \text { kurtarmayardım }=3 \text { kılavz }=2 \text { gemitipi }=1 \text { bayrakty }=2\end{array}$ & 77 & 0.1043 \\
\hline 11 & $\begin{array}{l}\text { başiter }=2 \text { rüzgar }=1 \text { görüs }=1 \text { cankaybı }=2 \text { yaralanma }=2 \text { kayıp }=2 \text { insankurtarma }=2 \\
\text { tıbbitahliye }=2 \text { kirlilik }=2 \text { kurtarmayardım }=3 \text { kılavz }=2 \text { bölge }=3 \text { gemitipi }=1\end{array}$ & 76 & 0.1029 \\
\hline 12 & $\begin{array}{l}\text { başiter }=2 \text { görüs }=1 \text { cankaybı }=2 \text { yaralanma }=2 \text { kayıp }=2 \text { insankurtarma }=2 \\
\text { tıbitahliye }=2 \text { kirlilik }=2 \text { kurtarmayardım }=3 \text { geminindurumu }=1 \text { kılavz }=2 \\
\text { gemitipi }=1 \text { bayrakty }=2\end{array}$ & 76 & 0.1029 \\
\hline 13 & $\begin{array}{l}\text { başiter }=2 \text { rüzgar }=1 \text { görüs }=1 \text { cankaybı }=2 \text { yaralanma }=2 \text { kayıp }=2 \text { insankurtarma }=2 \\
\text { tıbbitahliye }=2 \text { kirlilik }=2 \text { maddihasar }=2 \text { operasyon }=1 \text { kılavz }=2 \text { gemitipi }=1\end{array}$ & 75 & 0.1016 \\
\hline 14 & $\begin{array}{l}\text { başiter }=2 \text { rüzgar }=1 \text { görüs }=1 \text { cankaybı }=2 \text { yaralanma }=2 \text { kayıp }=2 \text { insankurtarma }=2 \\
\text { tıbbitahliye }=2 \text { kirlilik }=2 \text { kurtarmayardım }=3 \text { geminindurumu }=1 \text { kllavz }=2 \\
\text { gemitipi }=1\end{array}$ & 75 & 0.1016 \\
\hline 15 & $\begin{array}{l}\text { rüzgar }=1 \text { görüs }=1 \text { cankayb } 1=2 \text { yaralanma }=2 \text { kayıp }=2 \text { insankurtarma }=2 \\
\text { tbbitahliye }=2 \text { kirlilik }=2 \text { maddihasar }=2 \text { geminindurumu }=1 \text { operasyon }=1 \\
\text { gemitipi }=1 \text { bayrakty }=2\end{array}$ & 74 & 0.1002 \\
\hline
\end{tabular}

13'lü veri setlerinin 15 ve 9 . Siralardaki birliktelikleri incelendiğinde gemitipi-1 (kuru/dökme yük gemileri) için başiter-2 (baş iter yok) ve yükdurumu-1 (yüklü gemi) oluşu, geminin operasyon-1 (seyir) halinde olması ve bayrakty-2 (yabancı bayrak) değişkenleri yerine devreye girdiğinde kaza sayısında az da olsa bir artış gözlemlenmekte (74-77), 11 numaralı birliktelikte bulunan bölge-3 (Marmara denizi İstanbul boğazı) değişkeni değerlendirilmeye tabi tutulduğunda ise geminin yükdurumu-1 (yüklü gemi) oluşu kaza frekans değerinde dikkat çekici bir artışa sebep olmamıştır (76-77). 13'lü birliktelikler genel olarak incelendiğinde kaza oluşumunda göze çarpan değişkenlerin; gemitipi-1 (kuru/dökme yük), kılavuz-2 (kılavuz kaptan yok), bayrakyt-2 (yabanc1 bayrak), başiter-2 (baş iter yok), yükdurumu-1 (yüklü gemi) ve operasyon-1 (seyir) gibi etmenler olduğu gözlemlenmektedir. On üçlü nitelikler kümesi içinde kaza frekans değerleri en düşükten (74) en yükseğe (94) şeklinde birlikteliklerin incelemesi yapıldığındaysa kaza frekansını yükselten önemli değişkenler:

> gemitipi $=1 \quad$ (kuru/dökme yük), bayrakty $=2$ (yabancı bayrak), operasyon=1 (seyir) 
$>$

k1lavuz $=2$ (k1lavuz kaptan yok)

$>\quad$ bölge $=3$ (Marmara denizi-İstanbul

boğazı)

> yükdurumu=1 (yüklü gemi)

$>$ başiter=2 (baş iter yok) şeklinde siralanmakta ve bu değişkenlerin kaza frekanslarında bir artışa sebep olduğu gözlemlenmektedir.

Bütün birliktelik grupları kendi içinde ve birbirleriyle kıyaslanarak değerlendirildiğinde ise öne çıkan etmenler; geminin yüklü oluşu, seyir halinde olması, gemide k1lavuz kaptan olmayışı, baş iter yokluğu, sakin hava ve görüsş koşullarının iyi olduğu zamanlarda gerçekleşmesi, birliktelik içindeki gemilerin yabancı bayrak olması, kuru/dökme yük gemisi olması ve bölgesel olarak yerel ve uluslararası gemi trafiğinin diğer bölgelere nazaran daha yoğun olduğu Marmara denizi/ İstanbul boğaz bölgesi şeklinde göze çarpmaktadır. Bulgulardan kılavuz kaptan olmayışının kaza riskini artırdığı yönündeki sonuç (Ulusçu ve ark., 2009; Ece, 2015; Şahin ve Chan, 2017) sonuçlarıyla uyumludur. Kaza birliktelik sonuçları içerisinde ise kaza çıktısı olarak en çok; yaralanma, ölüm, kayıp, deniz kirliliği, maddi hasar ve kurtarma yardım talebi ile sonuçlanan kazaların oluşmadığı görülmüştür.

\section{TARTIŞMA ve SONUÇ}

Yapılan analiz neticesinde elde edilen bilgiler 1şığında alınan her türlü ek tedbire rağmen kazaların gerçekleşme oranlarında ciddiya da istikrarlı bir değişimin oluşmadığı görülmüştür. Bununla birlikte artan gemi trafiğine ve yaşanan kaza oranına bakarsak oransal olarak bir azalma olduğunu söyleyebiliriz. Veriler her ne kadar tek bir kaynaktan elde edilse de oluşturulmasından sorumlu kişilerin kaza bildirim raporları içinde bulunan ve doldurulması gereken bilgilerin tamamını doğru ve tam biçimde doldurmadığından değişkenlerin tespit süreci uzamış, bazı kazaların sürecin dışında tutulması gerekliliği oluşmuştur.

Türleri açısından kazalar değerlendirildiğinde, edinilen veriler doğrultusunda dünya genelinde olduğu gibi ülkemiz içinde de yaşanan kaza tipi değişmemiş ve ilk sırayı çatışma almıştır. $\mathrm{Bu}$ durum da bize operasyonel açıdan gemi adına en tehlikeli/riskli işlemin seyir olduğunu göstermektedir. Buna paralel olarak yaşanan kazaların çoğunluğunun, deniz trafiğinin en yoğun olduğu Türk boğazları ve Marmara denizinde gerçekleştiği görülmektedir. Aynı noktadan hareketle, yerel trafik te göz önünde tutulduğunda kazalarda ilk sırayı Türk bayraklı gemilerin alması kaçınılmaz olmuştur. En çok kazaya karışan gemi tipini de, dünya deniz ulaştırma sektöründe ilk sırada yer alan ve dünya genelinde olduğu gibi kuru/ dökme yük gemileri oluşturmaktadır.

İçerik analizlerinden elde edilen en çarpıcı sonuçlardan bir başkası ise gemilerin kazaya karışma zamanı olarak gözükmektedir. 07:3019:30 arasında oluşan kazaların oranı günün diğer yarısında yaşanan kazalardan daha fazla olduğu belirlenmiştir. Ayrıca kazalarda "vardiyaların ilk yarım saati ile son yarım saati" şeklinde ifade edebileceğimiz zaman diliminde oluşan kazaların toplam kazalar içinde yaklaşık 1/3'lük bir yer tuttuğu görülmektedir. Belirtilen miktarın 24 saatlik dilim içinde gerçekleştiğini dikkate aldığımızda "adaptasyon ve motivasyon" eksikliğinin gemi kazalarında önemli yer tuttuğunu söylemek mümkündür.

Birliktelik kuralı ile yapılan analiz sonucu kazalar değerlendirildiğinde ise kaza zamanının yaşanan birliktelikler içerisinde yer almadiğ 1 görülmektedir. Bunun sebebi ise kaza zamanlarının vardiya giriş-çıkış/gece-gündüz gibi durumları da dikkate alarak, yorgunluk, motivasyon ve adaptasyon eksikliği adına on dokuz ayrı bölümden oluşan geniş bir değerlendirmeye tabi tutulmasıdır. Birliktelik analizinde çıkmasa da bu sinıflandırma neticesinde yaşanan kazaların hemen hemen üçte birinin vardiyaların ilk ve son yarım saati olarak değerlendirebileceğimiz zaman aralığında gerçekleştiği içerik analizi sonucu tespit edilmiştir. $\mathrm{Bu}$ da, vardiyalarda adaptasyon eksikliği, yorgunluk gibi durumların kazalardaki payının ne denli önemli olduğunu ortaya koymaktadir.

Birliktelik kuralı ile kazaya karışan gemilerin analiziyle elde edilen bir diğer husus ise teknik donanım bakımından gemilerde baş iterin olmayışıdır. Bununla birlikte gemilerde kılavuz kaptanın olmayışı da dikkat çekici başka bir 
husus olarak karşımıza çıkmaktadır. Birden çok bilinmeyenin dâhil olması neticesinde yaşanan kazaları önlemek adına bulunduğu bölgedeki hâkim koşulları bilen kişilerin yol göstermesi, kaza oranlarının/ etkilerinin azalmasına katkı sunmasına vesile olabileceği gibi, tecrübenin de kaza önlemedeki önemini ortaya koymaktadır.

Bir diğer önemli nokta ise kazaların olumsuz hava şartları yerine, görüşün ve deniz durumunun engel teşkil etmediği durumlarda oluşmuş olmasıdır. Bu durumu, bilinen en büyük kaza nedeninin "personel hatası", kaza tipinin ise "seyir" olarak tanımlandığı kaza içerik analizleriyle birlikte değerlendirdiğimizde ise sakin havalarda, kısıtlı görüş koşullarının olmadığı günlerde kazaların daha çok olmasının sebebinin "rehavet" şeklinde tanımlanması gayet doğal olacaktır.

\section{ARAŞTIRMA KISITLARI}

Çalışmaya kaynak teşkil eden ve Türk karasularında meydana gelen Kaza/olay raporlarının tamamı AAKKM'de toplanmakta ve bu veriler UAB'nın sitesinde 03.10.2016 tarihine kadar kayıt altında ve erişime açık tutulmaktadır (UAB, 2017). Bu tarihten sonra sisteme veri girişi yapılmamıştır. 01.01.2007-03.10.2016 tarihleri arasında sistemde kayitlı 1378 kaza bulunmaktadır. $\quad 03.10 .2016$ ve 31.12.2017 tarihleri arasında yaşanan kazalarla ilgili ise BIMER üzerinden 25.03.2018 tarihinde AAKKM'de kayıtlı kazalar istenmiş, 16.04.2018 tarihinde cevap alınmıştır. 2016 yılının kalan bölümünde 69 kaza/olay, 2017 yılı içerisinde de 191 kaza/olay adedi, bir gemi için tanımlayıcı en önemli unsur olan IMO numarası olmadan tutulmuş Excel formatında iletilmiştir. Eksik veriler sebebiyle toplam 1623 kazadan 1012'si 31 değişkenle uygun formata getirilmiştir. Veri kodlaması yapılırken bu değişkenler içinde makine, pervane ve dümen tipi değişkenlerinin olduğu kaza sayılarının toplam kazalara oranı yaklaşık \%17 olduğundan, doğru çıkarımları yapabilmek adına bu üç değişken listeden çıkarılmıştır.

Tespit edilip kodlanan 1012 kaza/olaydan 274 ünün yapım tarihlerine ulaşılamadığından, daha doğru sonuçlar elde edebilmek adına yapım tarihi belirsiz tüm kaza/olaylar da listeden çıkarılmış ve veri madenciliği birliktelik kuralı analizi 738 kaza/olay ve 27 değişkenle gerçekleştirilmiştir. Çalışma sırasında denizciliğe önem veren gelişmiş ülkelerin kaza/ olay raporları incelenmiş ve bu noktada AAKM'nin yetersiz olduğu görülmüştür. Ülkemizde konuyla ilgili detaylı çalışma yapan bir diğer kuruluşta UAB'ye bağlı kaza araştırma ve inceleme komisyonudur. Burada düzenlenen kaza raporları gayet detaylıdır fakat 2010-2018 yılları arasinda toplam 39 rapor sunulmuştur. Yaşanan kazaların geneline bakıldığında bu oran yaklaşık $\% 0.25$ oranında ve çok yetersizdir.

\section{6. ÖNERILLER}

En hafif etkisi maddi hasar olan deniz kazası sonucunun büyük çevresel felaketlere dönüşmesi riski, her zaman ciddi bir tehdit olarak ülkelerin ve yaşayan tüm canlıların en önemli sorunları arasında bulunmaktadır. $\mathrm{Bu}$ bağlamda personelin, özellikle geminin sevk ve idaresinden sorumlu kişilerin dişardanbir göz ve bağımsız olan eğitim kurumlarınca, belirli dönemlerde farkındalıklarını artırmak adına kısa süreli eğitimlere tabi tutulmaları, kişilerdeki emniyet kültürünün gelişmesine yardımcı olacaktır. Böylece 24 saat faaliyetin sürdüğü ve ciddi riskler taşıyan gemi operasyonları için daha dikkatli hareket etmelerine ve dolayısıyla yaşanabilecek olumsuzlukların önüne geçmelerine yardımcı olabilecektir. Çalışmada, gemilerde baş iter olmayışının kaza frekansını $\operatorname{artırdığ~} 1$ tespit edilmiştir. $\mathrm{Bu}$ hususla ilgili gemilerin modernizasyonunun bir anda gerçekleştirilemeyeceği düşünülürse bu tür gemiler için seyir emniyetini artırmak adına yönetmelikler yeniden düzenlenerek limanlarda römorkör zorunluluğu, boğaz geçişlerinde römorkör (refakat) zorunluluğu getirilebilir. Kaza frekansını artıran bir diğer etmen ise gemilerde kılavuz kaptan olmayışı olarak göze çarpmaktadır. Önceki çalışmlarla uyumlu olan bu durum göz önüne alındığında özellikle boğaz geçişleri ve Marmara denizi için gemilerin risk değerlendirmesi önceden yapılarak gerekli durumlarda deniz, can ve mal emniyeti adına zorunlu kılavuzluk hizmeti risk puanına göre yeniden düzenlenebilir. Boğazlarda büyük yer kaplayan yerel trafiği oluşturan unsurlarda 
görevli çalışanlar için düzenli aralıklarla ve zorunlu olarak farkındalık eğitimleri verilebilir.

\section{Gelecek Calıșmalar için Öneriler:}

- Araştırmaya konu olan kazaların elde edilmesi yönündeki kısıtların ortadan kalkması ve daha çok veri ile analiz edilerek ilerleyen yıllarda tekrar yapılması faydalı olacaktır.

- Sonraki çalışmalarda yeni veri setleri ile değişik ve farklı veri madenciliği algoritmaları denenerek karşılaştırma yapilabilir.

- Gelecekte kıyıdaş ülkelerden elde edilecek verilerle çalışma yapılarak karşılaştırmalı değerlendirmelerde bulunarak bölgesel benzerlikler ortaya konulabilir.

- Gelecekte birden çok yöntemin denenmesi suretiyle deniz kazaları ile ilgili en etkin analiz yöntemi bulunabilir.

- Gelecekte daha fazla, güçlü ve tutarlı veri kullanarak her bölge için ayrı analizler yapılıp bölgesel olarak kaza farklılıkları ve sonuçları değerlendirilerek bölgesel politikalar geliştirilebilir.

- Gelecekte trafiğgin çok yoğun olduğu bölgeler için veri madenciliği yöntemiyle gemi kazalarından kaynaklı deniz kirliliği analizi yapılarak kirlilikle mücadele için öneriler geliştirilebilir.

\section{AÇIKLAMA BİLDİRIMI}

Yazarlar bu makalede çıkar çatışması olmadığını beyan ederler.

\section{ORCID Numaraları}

Ahmet KARABACAK:

(D) https://orcid.org/0000-0002-9040-1849

Burak KÖSEOĞLU:

(iD) https://orcid.org/0000-0003-0830-0385

\section{KAYNAKLAR}

Acharya, T.D., Yoo, K.W., Lee, D.H., (2017). GIS-based Spatio-temporal Analysis of Marine Accidents Database in the Coastal Zone of Korea. Journal of Coastal Research (The 2nd International Water Safety Symposium, Special Issue) 79: 114-118.
Akten, N., (2006). Gemi Kazaları: Çevre İçin Ciddi Bir Tehdit. Journal of Black Sea/Mediterranean Environment 12(1): 269-304.

Akyüz, E., (2016). A Marine Accident Analysing Model to Evaluate Potential Operational Causes in Cargo Ships. Safety Science 92: 17-25.

Asyalı, E., 2014. Gemi Kazaları Nedenleri ve İnsan Faktörü, Ulaştırma, Denizcilik ve Haberleşme Bakanlığı Deniz Kazalarını Araştırma ve İnceleme Çalıştayı, http://www.kugm.gov.tr/BLSM WIYS/KAIK/tr/Doc/ 20140228 095711 76347_1_64.pdf, 18-19 Ocak, Antalya.

Aydogdu, Y.D., (2013). A Comparison of Maritime Risk Perception and Accident Statistics in the Istanbul Straight. The Journal of Navigation 67: 129-144.

Baker, C.C., Seah, A.K., (2004). Maritime Accidents and Human Performance: the Statistical Trail. Martech 2004:225-239

BSU (Bundesstelle für Seeunfalluntersuchung), (2015). 2015 Annual Report. Germany: Federal Bureau of Maritime Casualty Investigation.

BSU (Bundesstelle für Seeunfalluntersuchung), (2016). 2016 Annual Report. Germany: Federal Bureau of Maritime Casualty Investigation.

BSU (Bundesstelle für Seeunfalluntersuchung), (2017). 2017 Annual Report. Germany: Federal Bureau of Maritime Casualty Investigation.

BSU (Bundesstelle für Seeunfalluntersuchung), (2018). 2018 Annual Report. Germany: Federal Bureau of Maritime Casualty Investigation.

BSU (Bundesstelle für Seeunfalluntersuchung), (2019). 2019 Annual Report. Germany: Federal Bureau of Maritime Casualty Investigation.

Changhai, H., Shenping, H., (2018). Factors Correlation Mining On Maritime Accidents Database Using Association Rule Learning Algorithm. Cluster Computing 586-595.

Chauvin, C., Lardjane, S., Morel, G., Clostermann, J., Langard, B., (2013). Human and organisational factors in maritime accidents: Analysis of collisions at sea using the HFACS. Accident Analysis and Prevention 59: 26-37.

Chen, C., Khoo L.P., Chong, Y.T., Yin, X.F., (2013). Knowledge Discovery Using Genetic Algorithm For Maritime Situational Awareness. Expert Systems with Applications 41: 2742-2753. 
Dalton, T., Jin, D., (2010). Extent and frequency of vessel oil spills in US marine protected areas. Marine Pollution Bulletin 60(2010): 1939-1945.

Davies, A.J., Hope, M.J., (2015). Bayesian InferenceBased Environmental Decision Support Systems For Oil Spill Response Strategy Selection. Marine Pollution Bulletin 96: 87-102.

Dikis, K., Lazakis, I., (2019). Dynamic Predictive Reliability Assessment Of Ship Systems. International Journal of Naval Architecture and Ocean Engineering.

Dodunekov. S, Minchev, Z., Mitov, I., Ivanova, K., Dobrinkova, N., Boyvalenkov, P., Pavlov, R., Kelevedzhiev, E. (2012). Knowledge Discovery Methods and Tools and Continuous Situation Awareness Systems (the Bulgarian Academic Approach). Mathematic and Informatics Bulgarian Academy of Science.

Ece, N.J., (2015). Kilavuzluk Hizmetlerinin Deniz Emniyetine Katkısı: İstanbul Boğazı'nda Kazaya Karışan Gemiler İle Kılavuz Kaptan Almaları Arasındaki İlişkinin Analizi. Journal of ETA Maritime Science 4(1): 3-21.

Ece, N.J., Özdemir, Ü., (2017). İstanbul ve Çanakkale Boğazları'nda Meydana Gelen Deniz Kazalarının Türleri ile Kılavuz Kaptan Alınması Arasındaki İlişkinin Analizi, 17. Kılavuzluk/Römorkör Servisleri ve Teknolojileri Kongresi, 27-28 Ekim 2017, s.75, İzmir.

EMSA (European Maritime Safety Agency), (2020). Annual Overview of Marine Casualties and Incidents.

Fayyad, U., (2001). The Digital Phisics of Data Mining. Communications of the ACM 44(3): 62-65.

Fricke, W., Cui, W., Kierkegaard, H., Kihl, D., Koval, M., Mikkola, T., Parmentier, G., Toyosada, M., Yoon, J.H., (2001). Comparative fatigue strength assessment of a structural detail in a containership using various approaches of classification societies. Marine Structures 15: 1-13.

Han, J., Kamber, M. (2001). Data Mining: Concepts and Techniques. Burnaby: Morgan Kaufmann Publishers.

Hanzu-Pazara, R., Barsan., E., Arsenie, P., Chiotoriou, L., Raicu, G., (2008). Reducing of maritime accidents caused by human factors using simulators in training process. Journal of Maritime Research 5(1): 3-18.

Hassel, M., Asbjørnslett, B.E., Hole, L.P., (2011). Underreporting of maritime accidents to vessel accident databases. Accident Analysis and Prevention 43(2011): 2053- 2063.
IMO (International Maritime Organization) (2018). 08.02.2018, GISIS (Global Integrated Shipping Information System), Marine Casualties and Incidents http://gisis.imo.org/Public/MCI/Search.aspx?Mode=A dvanced.

JTSB (The Japan Transport Safety Board Statistics Marine Accident), (2021). 01/03/2021, http://www.mlit.go.jp/jtsb/statisticsmar.html adresinden alınmıştır.

Ketkar, K.W., Babu, A.J.G., (1997). An Analysis of Oil Spills From Vessel Traffic Accidents. Transpn Res.D 2(1): 35-41.

Kondratenko, Y.P., Kondratenko, G.V., Pidoprigora, D.M., Sidorenko, S.A., Timchenko, V.L., (2000). Fuzzy Approach for Design of Ship's Decision-Making Systems. IFAC Management and Control of Production and Logistics 1191-1196.

Kouamou, G., (2011). A Software Architecture for Data Mining Environment. In: "New Fundamental Technologies in Data Mining", InTech Publ., pp.241258.

Le Blanck, L.A., Wyckoff, P.G., (1988). A Strategic Success Factor Analysis of the New Orleans Vessel Traffic Service. Transportation Journal 28(1): 44-50.

Le Blanc, L.A., Rucks, C., (1996). A Multiple Discriminant Analysis Of Vessel Accidents. Accid. Anal. And Prev. 28(4): 501-510.

MARDEP, Hong Kong Marine Accident, (2019). 01.03.2021, https://www.mardep.gov.hk/en/publication/ereport.ht $\underline{\mathrm{ml}}$ adresinden alınmıştır.

Macrae, C., (2009). Human factors at sea: common patterns of error in groundings and collisions. Maritime Policy \& Management 36(1): 21-38.

Montewka, J., Hinz, T., Kujala, P., Matusiak, J., (2010). Probability Modelling Of Vessel Collisions. Reliability Engineering and System Safety 95: 573-589.

Talley, W.K., Jin, D., Powell, H.K., (2005). Determinants of crew injuries in vessel accidents. Maritime Policy \& Management 32(3): 263-278.

TSBC (Transportation Safety Board of Canada), Statistical Summary Marine Occurrences 2019, (2019). https://www.bst-tsb.gc.ca/eng/stats/ marine/2019/ssem-ssmo-2019.pdf. 
Türkistanlı, T., Kuleyin, B., (2019). Traınıng Situational Awareness and Decision Making For Preventıng Collision at Sea: A Theoretical Background. Mersin University Journal of Maritime Faculty (MEUJMAF) 1(1): 10-16.

UAB (Ana Arama Kurtarma Koordinasyon Merkezi), (2017). 23.03.2017, http://aakkm.udhb.gov.tr

Uğurlu, Ö., Köse, E., Yıldırım, U., Yüksekyıldız, E., (2013). Marine Accident Analysis for Collision and Grounding in Oil Tanker with FTA Method. Maritime Policy and Management 42(2): 163-185.

Ulusçu, Ö.S., Özbaş, B., Altıok, T., Or, İ., (2009). Risk Analysis of the Vessel Traffic in the Strait of Istanbul. Risk Analysis 29(10): 1454-1472.

UNCTAD (United Nations Conference on Trade and Development), (2000). 14.01.2018, Rewiev of Maritime Transport http://unctad.org/en/Docs/rmt2000_en.pdf

UNCTAD (United Nations Conference on Trade and Development), (2017). Rewiev of Maritime Transport, New York.

UNCTAD (United Nations Conference on Trade and Development), (2020). Review of Maritime Transport, New York.

WEKA, (2018). Machine Learning Software in Java, The University of Waikato, https://www.cs.waikato.ac.nz/ml/weka/index.html.

Witt, N.A.J., Sutton, R., Miller, K.M., (1995). A Track Keeping Neural Network Controller for Ship Guidance. Marine Dynamics Research Group 385-392.

Yang, B., Zhao, Z., Ma, J., (2018). Marine Accidents Analysis Based on Data Mining Using Kmedoids Clustering and İmproved A Priori Algorithm. IOP Conference Series: Earth and Environmental Science 189: $1-9$

Yıldırım, U., Uğurlu, Ö., Başar, E., (2015). Karaya Oturma Kazalarında İnsan Hatası: Konteyner Gemileri için Örnek Çalışma. Journal of ETA Maritime Science 3(1): $1-10$ 